\title{
23. HEAT FLOW THROUGH THE TOE OF THE BARBADOS ACCRETIONARY COMPLEX 1
}

\author{
A. T. Fisher ${ }^{2,3}$ and M. W. Hounslow ${ }^{4}$
}

\begin{abstract}
Thirty-four sediment and mudline temperatures were collected from six drill holes on ODP Leg 110 near the toe of the Barbados accretionary complex. When combined with thermal conductivity measurements these data delineate the complicated thermal structure on the edge of this convergent margin. Surface heat-flow values from Leg 110 (calculated from geothermal gradients forced through the bottom-water temperature at mudline) of 92 to $192 \mathrm{~mW} / \mathrm{m}^{2}$ are $80 \%$ to $300 \%$ higher than values predicted by standard heat flow vs. age models for oceanic crust, but are compatible with earlier surface measurements made at the same latitude. Measured heat flow tends to decrease downhole at four sites, suggesting the presence of heat sources within the sediments. These results are consistent with the flow of warm fluid through the complex along sub-horizontal, high-permeability conduits, including thrust faults, the major décollement zone, and sandy intervals. Simple calculations suggest that this flow is transient, occurring on time scales of tens to tens of thousands of years. High heat flow in the vicinity of $15^{\circ} 30^{\prime} \mathrm{N}$ and not elsewhere along the deformation front suggests that the Leg 110 drill sites may be situated over a fluid discharge zone, with dewatering more active here than elsewhere along the accretionary complex.
\end{abstract}

\section{INTRODUCTION}

Surface heat-flow values from accretionary complexes tend to be lower than those measured over normally sedimented oceanic crust of the same age (Watanabe et al., 1977; Sclater et al., 1980; Burch and Langseth, 1981). On a regional scale, low heat flow in these settings is thought to result from: (1) convection cells in the underlying mantle with downwelling limbs beneath trenches; (2) subduction and underthrusting of relatively cold oceanic lithosphere; (3) thermal decoupling between the underthrust and overriding plates (Burch and Langseth, 1981); and (4) high effective sedimentation rates (Langseth et al., 1980). More localized processes such as mass wasting (Abbott et al., 1986), advective heat transfer (Reck, 1987), and fluid venting (Kulm et al., 1986) may also contribute to the thermal anomalies (both high and low values) documented on a smaller scale.

Measurements of borehole tempertures in the vicinity of the Japan trench on DSDP Leg 57 (Langseth and Burch, 1980; Burch and Langseth, 1981) revealed low values, which were attributed to the thermal effects of underthrusting cold lithosphere beneath forearc and trench sediments. Geothermal gradients in the upper kilometer of sediment that extrapolate to unusually high temperatures at the basement surface may indicate fluid flow up through the sedimentary column (Burch and Langseth, 1981).

High heat flow measured near the Nankai Trough (Yamano et al., 1984) and between the Chile ridge and trench (Cande et al., 1987) is due to the subduction of unusually young oceanic crust, possible hydrothermal circulation through basement, upward heat advection (Yamano et al., 1984), and a recent ridgetrench collision (Cande et al., 1987).

Large-scale models of convergent margins (e.g., Hsui and Toksoz, 1979; Yamano et al, 1984) have failed to accurately predict the complicated thermal structure of accretionary forearcs,

\footnotetext{
${ }^{1}$ Moore, J. C., Mascle, A., et al., 1990. Proc. ODP, Sci. Results, 110: College Station, TX (Ocean Drilling Program).

${ }^{2}$ Rosenstiel School of Marine and Atmospheric Science, Division of Marine Geology and Geophysics, University of Miami, Miami, FL 33149.

${ }^{3}$ Now at Ocean Drilling Program, Texas A\&M University, 1000 Discovery Drive, College Station, TX 77840 .

${ }^{4}$ University of East Anglia, School of Environmental Sciences, United King.
}

mainly due to the widely varying processes inferred to be active in these regions. For example, many models of accretionary complexes include the presence of elevated pore pressures as a controlling factor in sediment structure and evolution (e.g., Bray and Karig, 1985; Shi and Wang, 1985) yet these excess pressures remain poorly constrained. Direct measurement of nearlithostatic fluid pressures in sediments is difficult (Biju-Duval, Moore, et al., 1984; Mascle, Moore, et al., 1988); models that include high fluid pressure have thus far been supported only by additional theoretical studies and indirect evidence, including observations of mud volcanos or other unusual physical structures, and geochemical and geothermal anomalies.

An extensive series of downhole measurements, including heat-flow experiments, was undertaken on Ocean Drilling Program Leg 110 to determine the extent and influence of fluid flow close to the deformation front of the Barbados accretionary complex (Fig. 1). Thirty-four sediment and bottom-water temperatures from six drill holes (Table 1) and several hundred thermal conductivity determinations were used to calculate heat flow through the toe of the prism.

\section{EXPERIMENTAL METHODS}

Temperatures were measured with two different tools on ODP Leg 110, the Von Herzen Advance Piston Corer instrument (APC tool) and the Barnes-Uyeda temperature/pore-water/pressure sampler (T-probe). Both tools monitored the resistance of a single thermistor, with a nominal resolution of $10 \mathrm{ohms}$ or about $0.006^{\circ} \mathrm{C}$.

The APC tool consists of a thermistor/recorder package and a separate battery power supply mounted inside an annular cavity in the wall of the piston corer cutting shoe (Horai and Von Herzen, 1985). Temperature measurements were taken for 5 to 10 min during core collection while the cutting shoe and core barrel were rested at maximum penetration ( $9.5 \mathrm{~m}$ ahead of the bit). Estimated equilibrium temperatures were determined by fitting synthetic cooling curves to the results from each deployment and extrapolating to infinite time (Koehler and Von Herzen, 1986).

Use of the T-probe required suspension of coring operations and a separate tool lowering (Yokata et al., 1980). The T-probe was rested in bottom only 45 to $105 \mathrm{~cm}$ ahead of the bit at maximum extension. Measured temperatures were extrapolated to estimated equilibrium according to a theory modified from Bullard (1954). Both the APC tool and Tprobe allowed variable data recording intervals; tool properties are summarized in Table 2.

Thermal conductivities were measured on the JOIDES Resolution by the needle-probe method (Von Herzen and Maxwell, 1959) and cor- 


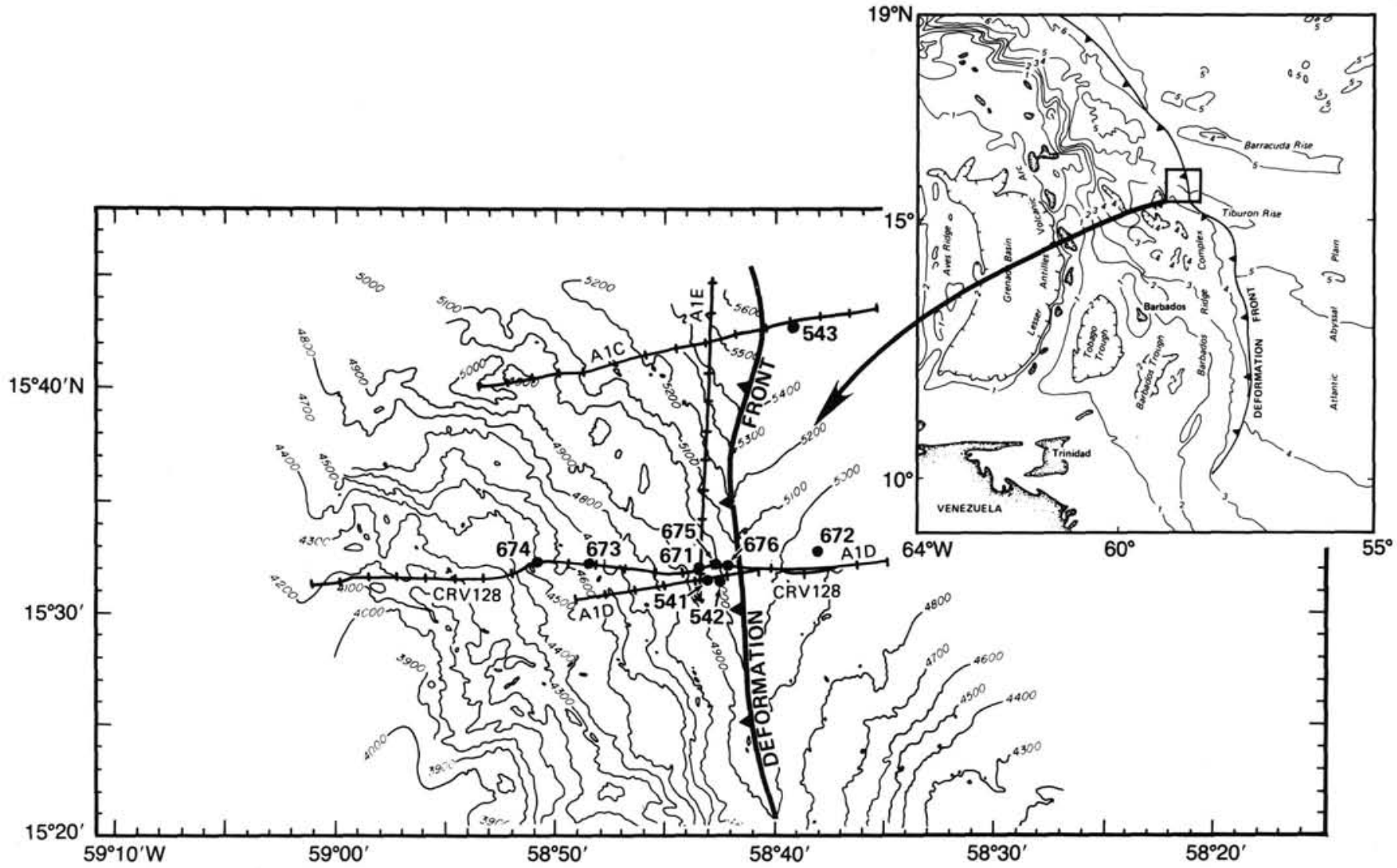

Figure 1. Map of study area, indicating locations of drill sites from ODP Leg 110 and DSDP Leg 78A. CRV-128 is a multichannel seismic line, discussed in detail by Mascle et al. (this volume). Bathymetry in meters.

Table 1. Drill holes where heat-flow data were gathered, including locations, water depth, and number of measurements in each.

\begin{tabular}{ccccc}
\hline Hole & $\begin{array}{c}\text { Lat } \\
(\mathrm{N})\end{array}$ & $\begin{array}{c}\text { Long } \\
(\mathrm{W})\end{array}$ & $\begin{array}{c}\text { Water } \\
\text { depth }(\mathrm{m})\end{array}$ & $\begin{array}{c}\text { Number of temperature } \\
\text { measurements }\end{array}$ \\
\hline $671 \mathrm{~B}$ & $15^{\circ} 31.55^{\prime}$ & $58^{\circ} 43.95^{\prime}$ & 4914.5 & 5 \\
$672 \mathrm{~A}$ & $15^{\circ} 32.40^{\prime}$ & $58^{\circ} 38.46^{\prime}$ & 4875.0 & 6 \\
$673 \mathrm{~A}$ & $15^{\circ} 31.90^{\prime}$ & $58^{\circ} 48.60^{\prime}$ & 4660.8 & 2 \\
$673 \mathrm{~B}$ & $15^{\circ} 31.92^{\prime}$ & $58^{\circ} 48.49^{\prime}$ & 4679.8 & 3 \\
$674 \mathrm{~A}$ & $15^{\circ} 32.29^{\prime}$ & $58^{\circ} 51.09^{\prime}$ & 4549.8 & 9 \\
$676 \mathrm{~A}$ & $15^{\circ} 31.85^{\prime}$ & $58^{\circ} 42.20^{\prime}$ & 4993.8 & 9 \\
\hline
\end{tabular}

${ }^{1}$ Includes bottom water.

Table 2. Summary of principal properties of the APC tool and the T-probe.

\begin{tabular}{lccc}
\hline Instrument & $\begin{array}{c}\text { Instrument } \\
\text { housing }\end{array}$ & $\begin{array}{c}\text { Penetration } \\
\text { ahead of bit } \\
(\mathrm{m})\end{array}$ & $\begin{array}{c}\text { Recording } \\
\text { interval }\end{array}$ \\
\hline APC tool & $\begin{array}{c}\text { APC cutting shoe: } \\
\text { steel annular } \\
\text { cylinder }\end{array}$ & 9.5 & $\begin{array}{c}\text { Variable, } \\
\text { generally }\end{array}$ \\
& ID: $6.17 \mathrm{~cm}$ & & $10-20 \mathrm{~s}$ \\
& OD: $7.86 \mathrm{~cm}$ & & \\
T-probe & Steel cylindrical & $0.45-1.05$ & $\begin{array}{c}\text { Variable, } \\
\text { probe }\end{array}$ \\
& OD: $1.25 \mathrm{~cm}$ & & $5.12 \mathrm{~s}$ or \\
& & $60 \mathrm{~s}$ \\
\hline
\end{tabular}

rected for in-situ pressures and temperatures. The errors associated with estimating final equilibrium temperatures from best-fitting synthetic curves varied from 0.05 to $0.2^{\circ} \mathrm{C}$.

\section{MEASUREMENT CORRECTIONS}

\section{Temperature Corrections}

Detailed descriptions of tool deployment, plots of temperatures vs. time, discussion of data quality, and assumptions involved in reduction and intertool calibration are provided in Mascle, Moore, et al. (1988) (Introduction and Explanatory Notes, and individual site reports). Several errors were discovered in the software aboard the Resolution used to reduce the APC tool data as reported in Mascle, Moore et al. (1988) (K. Becker, pers. commun., 1987). These errors resulted in the geometry of the cutting shoe and thermal properties of the sediments being modeled improperly. The raw data have been reprocessed using a corrected program. The temperature values listed in this report differ significantly from those reported earlier (Mascle, Moore et al., 1988), but differences between adjacent measurements in any one hole are little changed. Thus conclusions drawn from the preliminary results still apply.

Sediments drilled on Leg 110 below the upper tens of meters were firm, so that the use of a "short T-probe" was required to prevent bending and wedging the tool in the bottom-hole assembly. The thermistor housing protruded 26 to $45 \mathrm{~cm}$ ahead of the bit in this configuration.

There was often a lag of 2 to $4 \mathrm{hr}$ between the cessation of drilling and penetration of the T-probe into the sediments at the bottom of the hole, during which water was circulated in the 
hole to keep it clear of fill. In addition, the T-probe was pumped down the drill pipe to speed its descent, and temperature measurements taken during tool descent indicated that the circulation fluids were near bottom-water temperature. We were concerned that the combined drilling and circulation disturbances might lower sediment temperatures measured with the short $\mathrm{T}$ probe.

To determine if corrections were needed for short T-probe measurements, we modeled the bottom of the borehole as the top of a semi-infinite half-space, and used the solutions for $T(t, z)$ in Carslaw and Jaeger (1959, pp. 599-60) for one-dimensional, conductive heat flow. We assumed that the temperature below hole bottom was initially at $T(z)=T_{\mathrm{w}}+g z$, where $T_{\mathrm{w}}$ is bottom-water temperature, $g$ is the initial geothermal gradient, and $z$ is depth. $T_{\mathrm{w}}$ was assumed to be $0.0^{\circ} \mathrm{C}$ for simplicity.

When the bit reaches some depth of interest $\left(z_{0}\right)$ at time $t=$ 0 , the bottom of the drill hole is subjected to a sudden decrease in temperature to $T_{\mathrm{w}}$. A temperature perturbation then propagates downward; sediment temperature, $T(z, t)$, can be calculated for any depth and time according to:

$$
T(z, t)=T_{0} \operatorname{erf}\left\{\frac{z-z_{0}}{2 \sqrt{\alpha t}}\right\}+g\left(z-z_{0}\right)
$$

where $T_{0}$ is the original sediment temperature at a depth $z_{0}, \alpha$ is the sediment thermal diffusivity, $t$ is the time since drilling reached $z_{0},\left(z-z_{0}\right)$ is the depth of penetration of the T-probe into the sediment, and erf is the error function.

Solutions to (1) are presented in Figure 2, with $T(z, t) / T_{0}+$ $g\left(z-z_{0}\right)$ ratio curves for depths of probe penetration varying from 5 to $30 \mathrm{~cm}$ over a time span of $6 \mathrm{hr}$. Because we neglected the effects of lateral heat transport and assumed low $T_{\mathrm{w}}$ and high $T_{0}$ and $\alpha$ values, this model should overestimate the thermal effects of fluid circulation in the hole. This analysis revealed that the thermal effect of water circulation in the hole

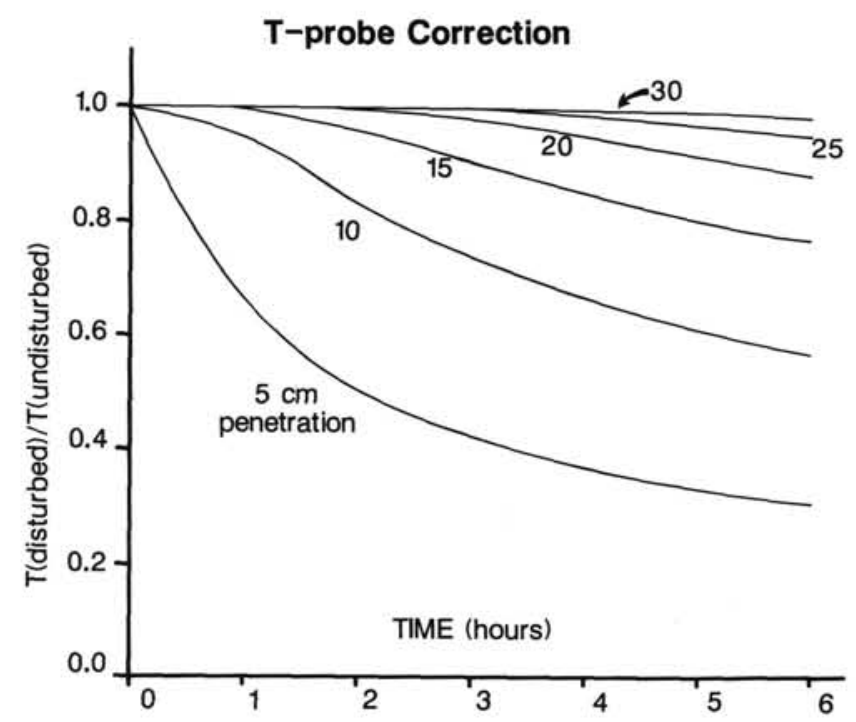

Figure 2. Curves showing the thermal effects of disturbances, due to drilling circulation, on temperatures measured with the T-probe. Thermal conductivity is assumed to be a uniform $1.4 \mathrm{~W} / \mathrm{m} \cdot{ }^{\circ} \mathrm{C}$, initial sediment temperature is assumed to be $15^{\circ} \mathrm{C}$. Curves are plotted for probe penetrations varying from 5 to $30 \mathrm{~cm}$. So long as the probe penetrates at least $25 \mathrm{~cm}$ within a few hours after drilling, the disturbance is less than $2 \%$. can be neglected provided the T-probe penetrates at least $25 \mathrm{~cm}$ into the sediment within 2 to $4 \mathrm{hr}$ of drilling. This model assumed that the bottom sediment was not fractured by the penetration of the probe, which could allow cold water to directly cool the thermistor housing. When the sediments were fractured, it was immediately obvious from the temperature record that the measured values were erroneous.

\section{Thermal Conductivity Corrections}

\section{Pressure Corrections}

The pressure correction of Ratcliffe (1960) would be about $2.7 \%$ for measurements on Leg 110. Morin and Silva (1984) conducted laboratory experiments on biogenic oozes and clays to document variations in physical properties under hydrostatic loads and demonstrated that porosity is strongly influenced by hydrostatic pressure. As sediment thermal conductivity is largely a function of porosity (Von Herzen and Maxwell, 1959), Morin and Silva (1984) have related thermal conductivity corrections directly to porosity. Their Figure 4 shows thermal conductivity corrections as a function of porosity. Corrections are noted for pressure increments of $10 \mathrm{MPa}$ (equivalent to about $1000 \mathrm{~m}$ of water depth under hydrostatic conditions). We bestfit their results to a power function of the conductivity correction per $1000 \mathrm{~m}$ water depth $\left(k_{\mathrm{c}}\right)$ vs. measured sediment porosity $(\phi)$ :

$$
\ln \left(k_{c}\right)=b \ln (a \varnothing)
$$

where $a$ and $b$ are empirically derived constants equal to 1.96 and 8.97 , respectively.

This correction method should be more accurate than that of Ratcliffe (1960) because it accounts for abrupt changes in porosity. Equation (2) provides corrections of $+1.0 \%$ to $+3.9 \%$ for thermal conductivities varying from 0.8 to $1.4 \mathrm{~W} / \mathrm{m} \cdot{ }^{\circ} \mathrm{C}$ when porosities vary from $50 \%$ to $80 \%$.

Leg 110 sediment porosities were taken from Mascle, Moore et al. (1988). Most porosities were evaluated within a few centimeters of a thermal conductivity measurement. Where no porosity data were available within $5 \mathrm{~cm}$ of a thermal conductivity measurement, values from above and below were interpolated. In-situ pressure was assumed to be hydrostatic with no provision made for "excess" fluid pressures.

\section{Temperature Corrections}

Temperature corrections (of $-0.193 \% /{ }^{\circ} \mathrm{C}$ ) were applied to all thermal conductivity measurements according to Morin and Von Herzen (1986), assuming a laboratory temperature of $24^{\circ} \mathrm{C}$. Corrections and final values are listed in Appendix A and plotted with temperature data from each drill hole (Figures 3 to 7). Thermal conductivity at each site was assumed to be 0.85 $\mathrm{W} / \mathrm{m} \cdot{ }^{\circ} \mathrm{C}$ from the surface down to the depth of the first measurement.

\section{TEMPERATURE GRADIENT AND HEAT-FLOW RESULTS}

Temperatures and heat-flow results from six drill holes are summarized in Appendix B. Downhole temperatures and sediment thermal conductivities are plotted side by side for each site in Figures 3 through 7. Corresponding thermal resistance (heat flow) plots for each site are presented in Figures 8 through 12 . Bottom-water measurements were made by pausing at mudline during each tool lowering and averaging the temperatures measured at each site.

Thermal gradients and heat-flow values were calculated between adjacent temperature measurements and over specific intervals of interest that included three or more temperatures. We 

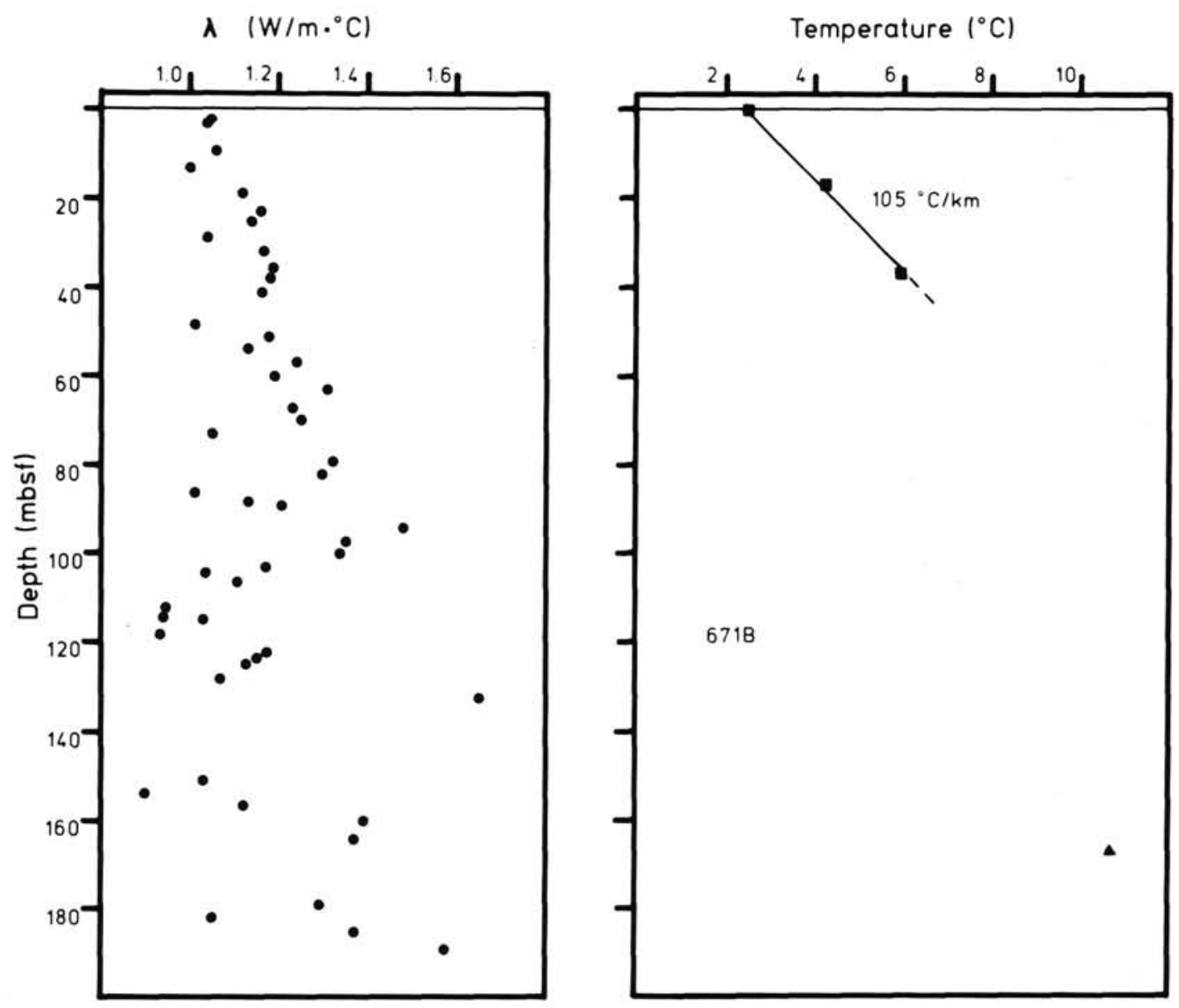

Figure 3. Downhole temperature and thermal conductivity values from Hole 671B. For figures 3 to 7 , thermal conductivity values have been corrected to in-situ conditions (Appendix A). Squares are APC tool temperatures and triangles are T-probe temperatures. Best-fitting thermal gradient through bottom water and upper two APC tool measurements is shown.

use the term "surface" heat flow to refer to values calculated from a thermal gradient that has been forced to pass through the temperature of bottom water at mudline.

Heat-flow values were calculated from the temperature and corrected thermal conductivity data by procedures described in Chapman et al. (1984) and Morin and Von Herzen (1986). Heat flow $(q)$ is determined from the temperature and the thermal resistance of the sediments where (Bullard, 1939):

$$
q=\frac{T-T_{0}}{R(z)}
$$

The thermal resistance, $R(z)$, is:

$$
R(z)=\int_{z_{0}}^{z_{1}} \frac{d z^{\prime}}{k\left(z^{\prime}\right)}
$$

where $z_{0}$ and $z_{1}$ are the depths at the bottom and top of the interval.

In this study, thermal resistance is estimated from discrete measurements in a depth interval by:

$$
R(z)=\sum_{i=1}^{n} \frac{\Delta z_{i}}{k_{i}} .
$$

The maximum estimated errors in these heat-flow calculations, including those associated with temperature and thermal conductivity measurements and corrections, are between $10 \%$ and $15 \%$.

\section{Site 671}

Site 671 is located approximately $4.5 \mathrm{~km}$ west of the deformation front of the Barbados accretionary complex. Three successful sediment temperature measurements were completed in Hole 671B, two with the APC tool and one with the T-probe. An attempt to measure the borehole fluid temperature before logging between 280 and $300 \mathrm{mbsf}$, resulted in an extremely poor-quality record that failed to yield a reliable temperature profile.

The thermal gradient in the upper $17 \mathrm{~m}$ of sediment is $114^{\circ} \mathrm{C} / \mathrm{km}$, decreasing to $92^{\circ} \mathrm{C} / \mathrm{km}$ from 17 to $36 \mathrm{mbsf}$, and to $36^{\circ} \mathrm{C} / \mathrm{km}$ between 36 and $168 \mathrm{mbsf}$ (Fig. 3). Heat flow over the same interval drops from $111 \mathrm{~mW} / \mathrm{m}^{2}$ near the surface to 42 $\mathrm{mW} / \mathrm{m}^{2}$ at depth (Fig. 8).

\section{Site 672}

Oceanic reference Site 672 is located $6 \mathrm{~km}$ east of the deformation front, over an 800-m-thick sediment section. Five successful sediment temperature measurements were made in Hole $672 \mathrm{~A}$, three with the APC tool and two with the T-probe (Fig. 4). 

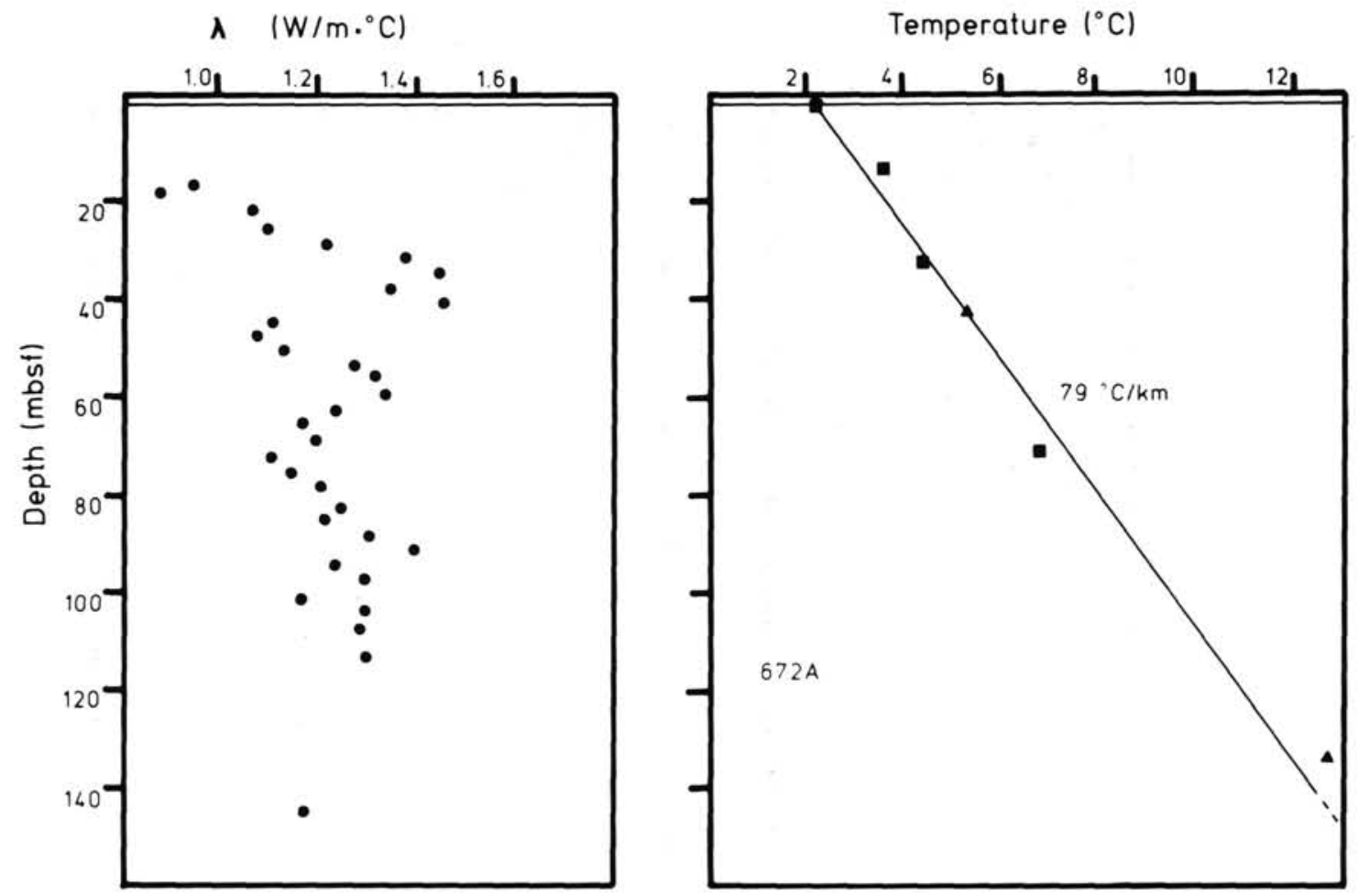

Figure 4. Downhole temperature and thermal conductiviity data for Hole 672A. Best-fitting thermal gradient through all measurements is shown.
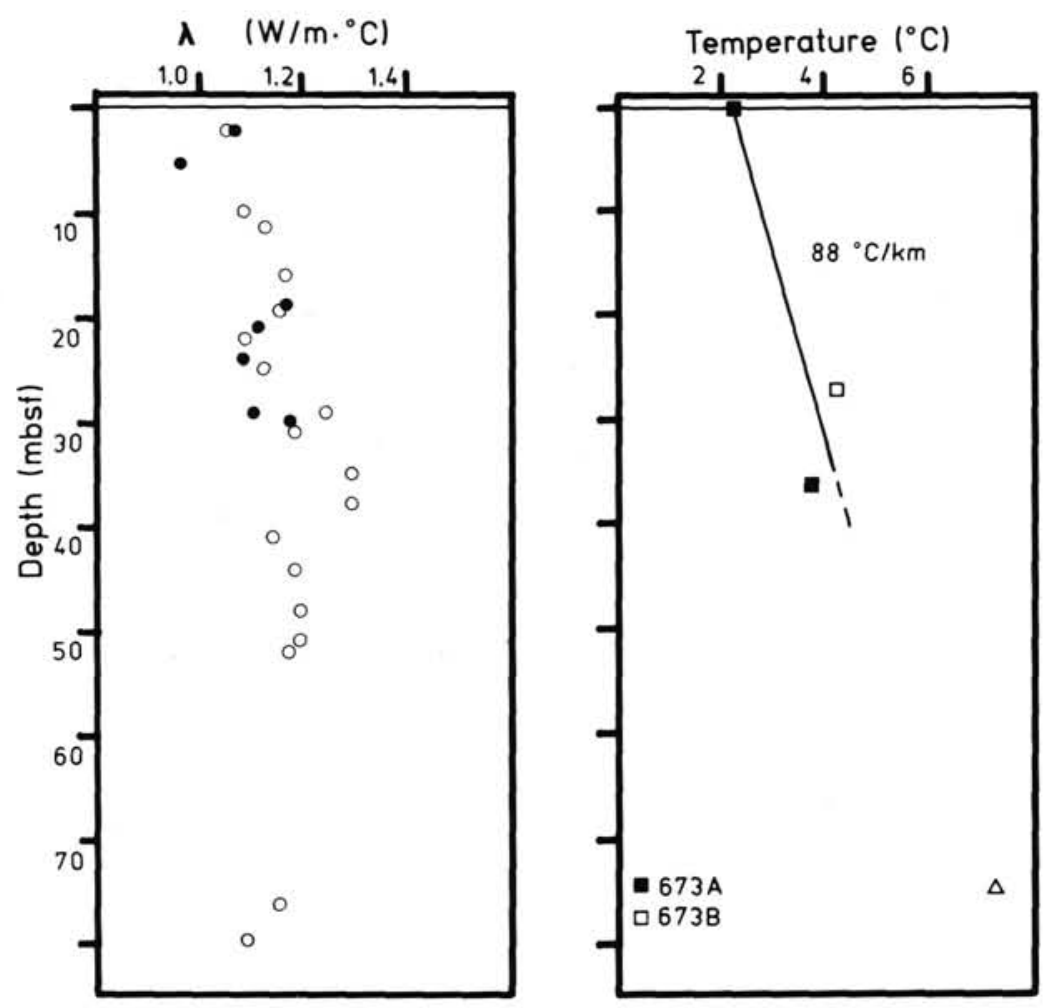

Figure 5. Downhole temperature and thermal conductivity data for Holes $673 \mathrm{~A}$ and 673B. Closed symbols are from 673A; open symbols are from 673B. Best-fitting thermal gradient through bottom water and upper two APC tool measurements is shown. 

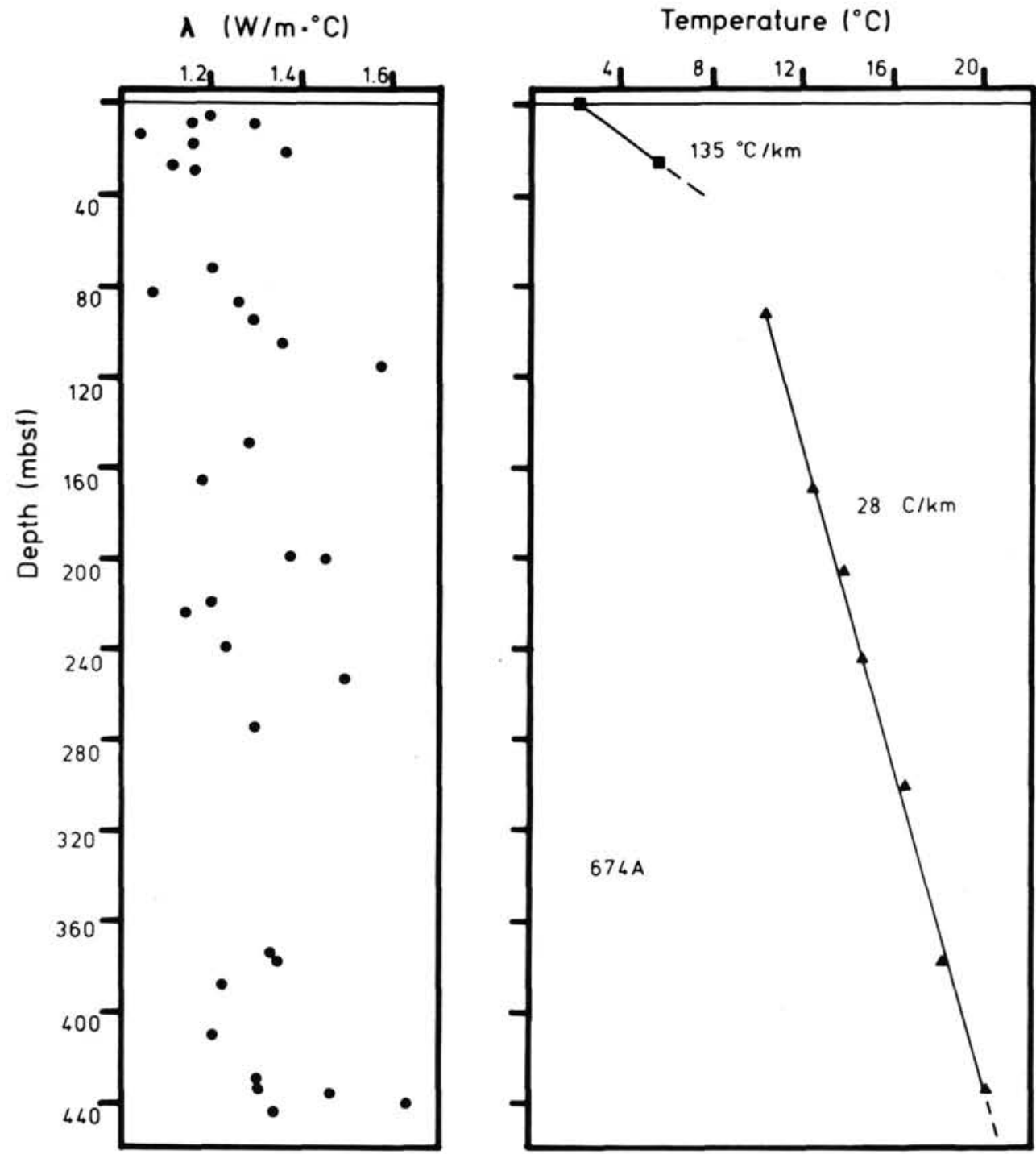

Figure 6. Downhole temperature and thermal conductivity data for Hole 674A.

The measured temperatures indicate an overall gradient of $79^{\circ} \mathrm{C} / \mathrm{km}$ to a depth of $134 \mathrm{mbsf}$ and heat flow of $92 \mathrm{~mW} / \mathrm{m}^{2}$, although the thermal gradient between successive measurements varied from $38^{\circ} \mathrm{C} / \mathrm{km}$ to $167^{\circ} \mathrm{C} / \mathrm{km}$. A high thermal conductivity layer between 30 and 40 mbsf accompanies a concomitant decrease in thermal gradient. Correcting for this change in thermal conductivity did not remove the nonlinearity from the heatflow plot (Fig. 9).

\section{Site 673}

Three sediment temperature measurements were made at Site $673,12 \mathrm{~km}$ upslope from the deformation front; two with the APC tool and one with the T-probe in Hole 673B (Figs. 5 and 10). The T-probe measurement at 75 mbsf in Hole 673B was probably infill or penetrated $<25 \mathrm{~cm}$ into the sediment (Mascle, Moore et al., 1988) and is thus a lower bound.

The APC tool measurements in Holes 673A and 673B yielded a calculated thermal gradient of $88^{\circ} \mathrm{C} / \mathrm{km}$ and heat flow of 97 $\mathrm{mW} / \mathrm{m}^{2}$ from the surface to $36 \mathrm{mbsf}$.

\section{Site 674}

Site 674 is $17 \mathrm{~km}$ landward of the deformation front, the farthest west of the Leg 110 drill sites. One APC tool and eight Tprobe measurements were made in Hole 674A (Fig. 6). The deepest measurement, at $\mathbf{4 3 4} \mathrm{mbsf}$, was probably infill or barely penetrated the sediment at the bottom of the hole and the final temperature from this run is thus a lower bound (Appendix B, and Fig. 6).

The surface gradient and heat flow calculated from the APC tool measurement and bottom water are $135^{\circ} \mathrm{C} / \mathrm{km}$ and 151 $\mathrm{mW} / \mathrm{m}^{2}$, respectively. The T-probe data from 92 to $434 \mathrm{mbsf}$ best fit a linear gradient of $28^{\circ} \mathrm{C} / \mathrm{km}$, providing a calculated heat flow of $37 \mathrm{~mW} / \mathrm{m}^{2}$ (Fig. 11).

\section{Site 676}

Eight sediment temperature measurements were made in Hole $676 \mathrm{~A}, 600 \mathrm{~m}$ landward of the deformation front, three with the APC tool and five with the T-probe (Fig. 7). 

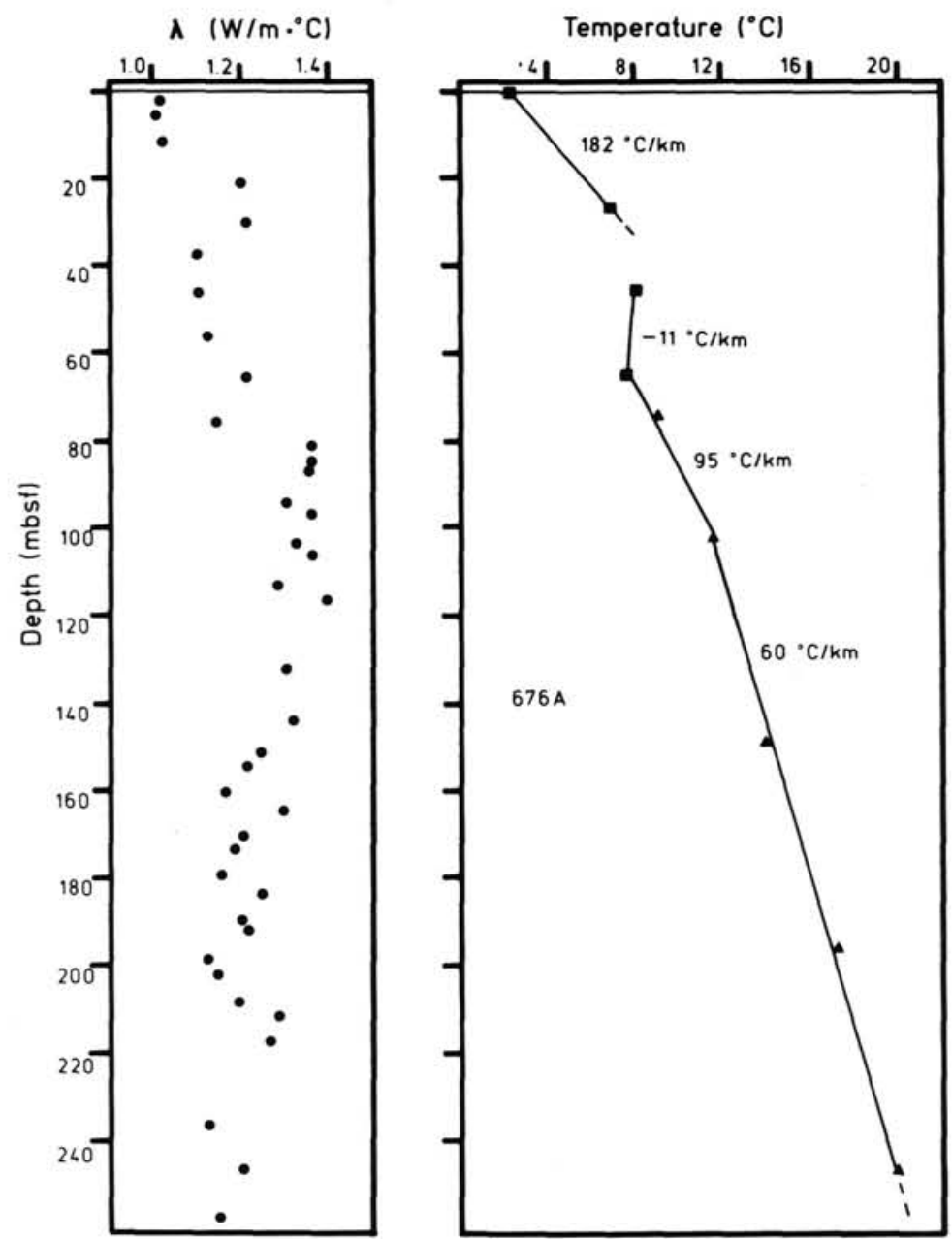

Figure 7. Downhole temperature and thermal conductivity data for Hole 676A. Note complicated thermal structure, including negative gradient between the lower two APC tool measurements.

Temperatures from Hole $676 \mathrm{~A}$ indicate that the most complex thermal structure observed on Leg 110 (Fig. 12). The gradient from mudline to a depth of $26 \mathrm{mbsf}$ is $182^{\circ} \mathrm{C} / \mathrm{km}$ with a calculated heat flow of $192 \mathrm{~mW} / \mathrm{m}^{2}$. The gradient and heat-flow decrease over the 26 - to 45 -mbsf interval to $63^{\circ} \mathrm{C} / \mathrm{km}$ and 72 $\mathrm{mW} / \mathrm{m}^{2}$, respectively.

Between 45 and 64 mbsf there is a decrease in sediment temperatures, with a measured gradient of $-11^{\circ} \mathrm{C} / \mathrm{km}$ and heatflow of $-12 \mathrm{~mW} / \mathrm{m}^{2}$. This reduction in sediment temperatures over a 19-m interval was recorded with a single APC tool, which was carefully calibrated before and after each deployment. The deepest APC tool measurement at $64 \mathrm{mbsf}$ and the first two Tprobe measurements at 74 and 102 mbsf yield a gradient of $95^{\circ} \mathrm{C} / \mathrm{km}$ and heat flow of $121 \mathrm{~mW} / \mathrm{m}^{2}$. The deepest four Tprobe measurements best fit a gradient of $60^{\circ} \mathrm{C} / \mathrm{km}$, resulting in heat flow of $74 \mathrm{~mW} / \mathrm{m}^{2}$.

\section{DISCUSSION}

A simple comparison of the water content of sediments seaward of the deformation front of the Barbados acretionary complex (DSDP Site 543; ODP Site 672) and sediments exposed on the island of Barbados suggests that a considerable quantity of pore water is expelled during deformation and uplift (e.g., Bray and Karig, 1985). Because water moving through sedi- ments is a much more efficient carrier of heat than conduction alone, it is to be expected that some of the heat flowing through the Barbados accretionary complex will be advected as a result of this dewatering.

Analyses of results from ODP Leg 110 and earlier surveys indicate that:

1. Heat flow in the vicinity of the deformation front at $15^{\circ} 30^{\prime} \mathrm{N}$ requires a substantial input of heat in addition to that released by cooling oceanic crust of Late Cretaceous age.

2. Large changes in thermal gradients with depth, high spatial variability of heat-flow values and persistence of geochemical anomalies in pore fluids (Gieskes et al., this volume) are created by the flow of warm fluids, primarily along subhorizontal conduits.

3. Fluid flow is transient.

Davis and Hussong (1984) suggested that high heat-flow values calculated from data at DSDP Site 541 may have resulted from fluid flow along the décollement zone west of the deformation front. These authors found no thermal anomaly at oceanic Site 543 , about $20 \mathrm{~km}$ north of Site 672 , only a geothermal gradient of about $30^{\circ} \mathrm{C} / \mathrm{km}$. Westbrook et al. (1986) conducted E-W geothermal traverses across the Barbados accretionary 


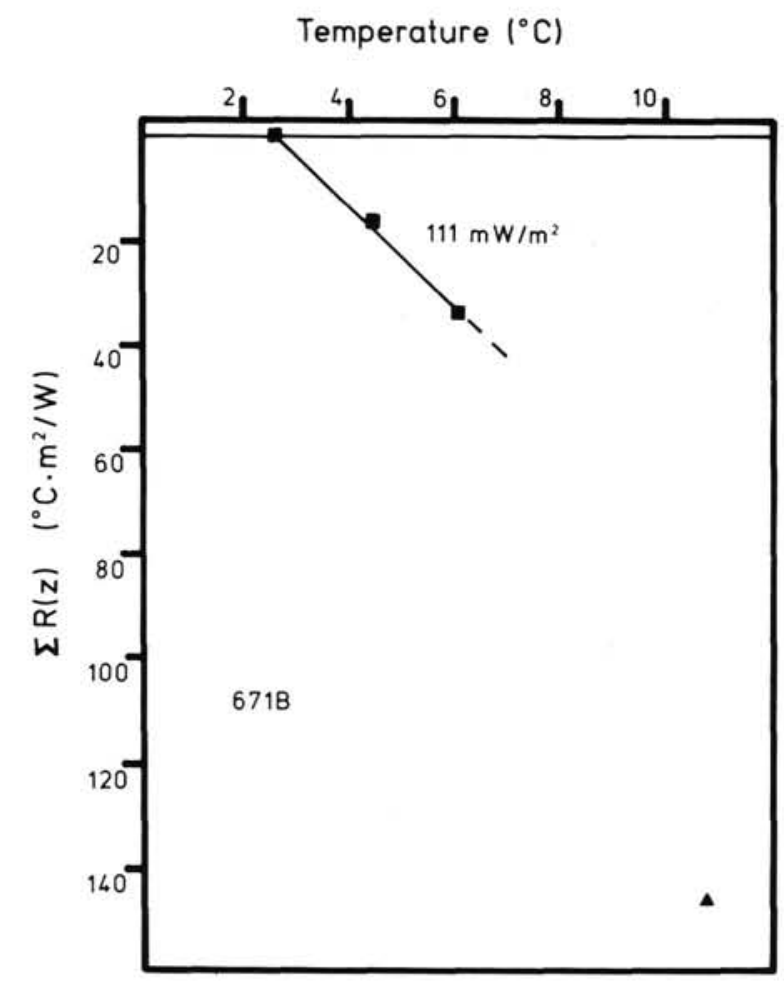

Figure 8. Temperature vs. cumulative thermal resistance for Hole 671B. Symbols as in Figure 4.

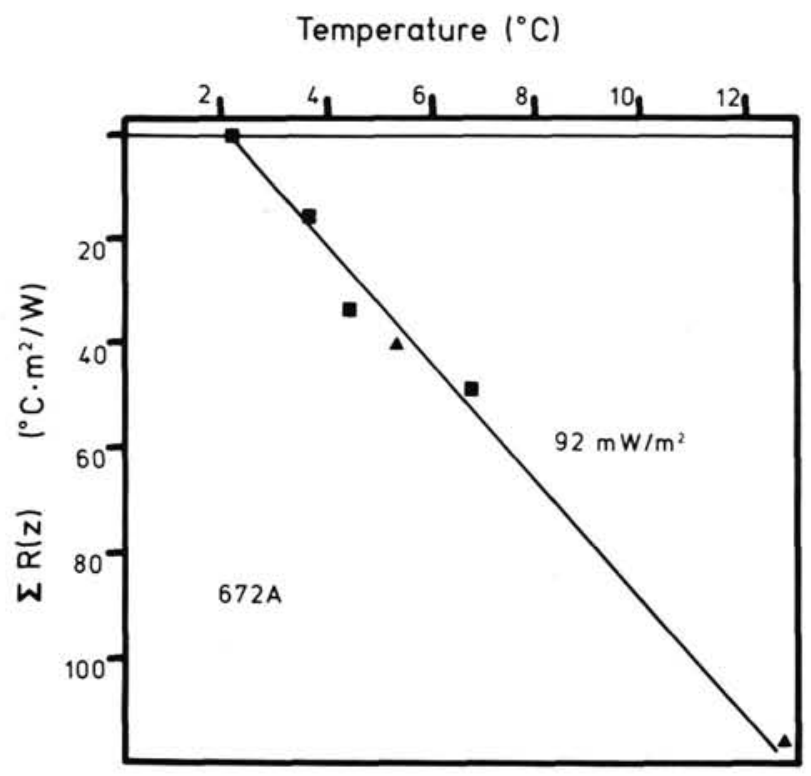

Figure 9. Temperature vs. cumulative thermal resistance for Hole $672 \mathrm{~A}$. Symbols as in Figure 4.

complex at $14^{\circ} 20^{\prime}$ and $14^{\circ} 35^{\prime} \mathrm{N}$ (about $130 \mathrm{~km}$ south of the Leg 110 drill sites). These authors reported basin heat-flow values of about $55 \mathrm{~mW} / \mathrm{m}^{2}$ that decreased landward across the complex. Exceptions to this trend were found on the eastern edge of the $14^{\circ} 20^{\prime} \mathrm{N}$ transect that crossed a mud volcano seaward of the deformation front (Langseth et al., 1988). Heatflow values near the deformation front at $15^{\circ} 30^{\prime} \mathrm{N}$ were also

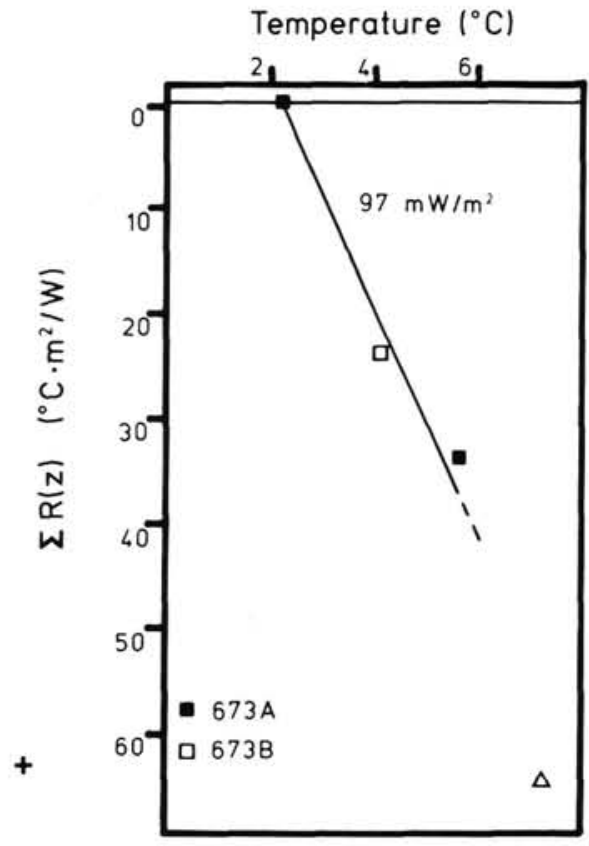

Figure 10. Temperature vs. cumulative thermal resistance for Holes $673 \mathrm{~A}$ and 673B. Symbols as in Figure 6.

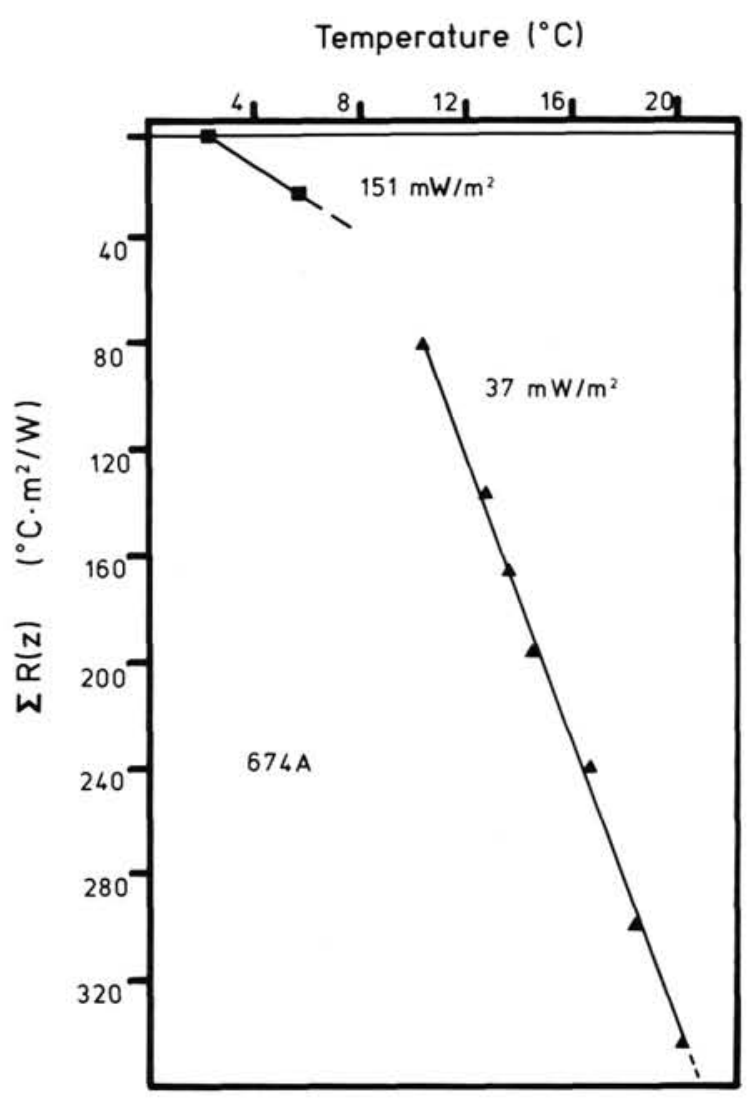

Figure 11. Temperature vs. cumulative thermal resistance for Hole 674 . Symbols as in Figure 4. 


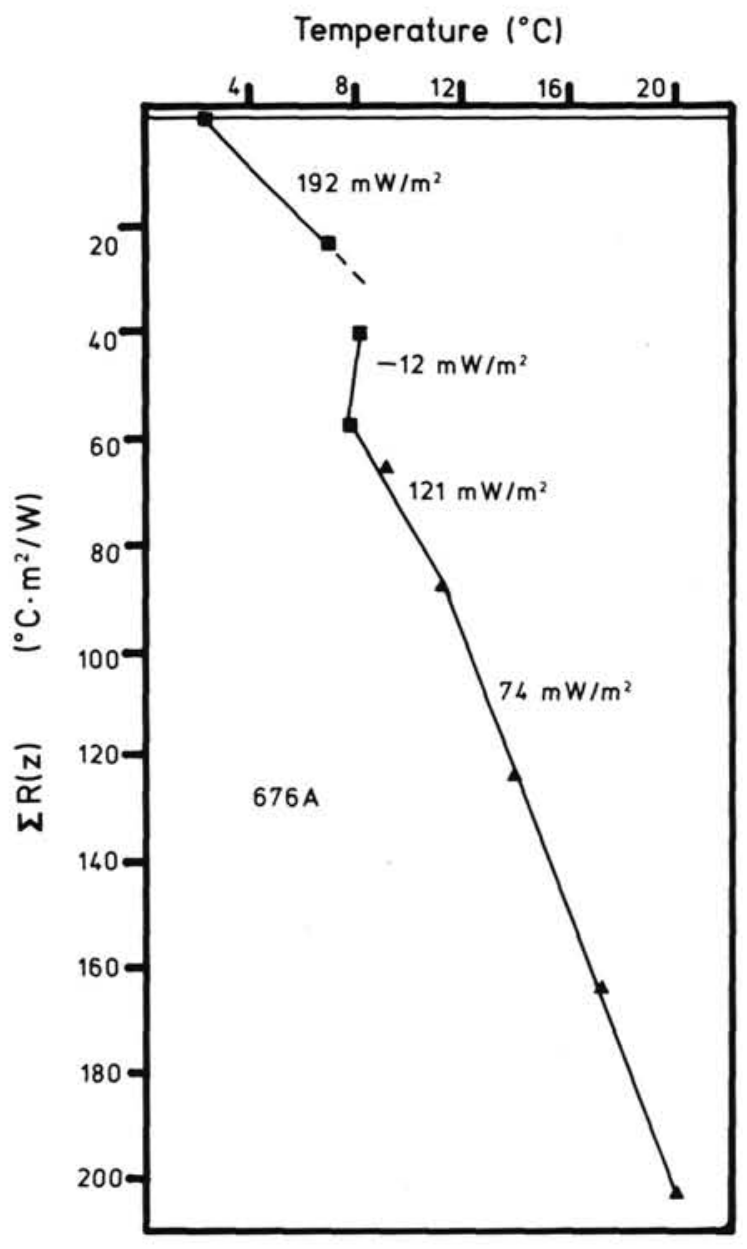

Figure 12. Temperature vs. cumulative thermal resistance for Hole 676A. Symbols as in Figure 4.

found to be anomalously high relative to the undisturbed basin to the east, leading Westbrook et al. (1986) to infer active fluid movement and expulsion of pore water.

The heat flow expected through upper Cretaceous (90 Ma) oceanic crust should be 45 to $53 \mathrm{~mW} / \mathrm{m}^{2}$ (Parsons and Sclater, 1977). The surface heat-flow values measured on Leg 110 range from a low of $92 \mathrm{~mW} / \mathrm{m}^{2}$ at Site 672 to a high of $192 \mathrm{~mW} / \mathrm{m}^{2}$ at Site 676 (Fig. 13). These values are two to four times higher than predicted based on crustal age, but are in agreement with the earlier seafloor measurements of Westbrook et al. (1986). The Leg 110 heat flow values calculated from "non-surface" measurements (with thermal gradients not forced through the temperature of bottom water at mudline) tend to be significantly lower, with values at Sites 671 and 674 falling below those predicted (Fig. 13). This variability of heat flow along strike and with depth suggests that localized processes may dominate heat flow. Explanations for the local variability of oceanic heat flow include conductive refraction due to sub-seafloor thermal conductivity variations and rough bathymetry, hydrothermal circulation through basement and sediments, and mass wasting. Each of these mechanisims will be examined briefly in an attempt to explain the observations.

Sloping thermal conductivity contrast boundaries may cause perturbations in surface heat flow (Sclater et al., 1970). To simulate the effects of such variations, we used a two-dimensional, finite-difference model, assuming constant heat input at the base, adiabatic side boundaries, and a top surface fixed at bottom-water temperature.

Sediment thermal conductivity was modeled with the porosity-depth relationships of Bullard and Day (1961) and Hamilton (1976) for terrigenous material; these values are in reasonable agreement with Leg 110 results. Crustal thermal conductivity was similarly related to porosity (Hyndman and Drury, 1976; Donnelly et al., 1980).

The effects of basement topographic variations were tested first. The depth to the top of basement through the toe of the prism was calculated from seismic line CRV 128 using a surface seismic velocity of $1.6 \mathrm{~km} / \mathrm{s}$ and a velocity increase with depth of $0.7 \mathrm{~km} / \mathrm{s}-\mathrm{km}$ (Mauffret et al., 1984). We assumed the following sediment porosity scheme (Whitmarch, 1979; Donnelly et al., 1980; Mascle, Moore et al., 1988): Depth $=0$ to $100 \mathrm{~m}, \phi$ $=25$ to $10 \%$; depth $=100$ to $1500 \mathrm{~m}, \phi=10$ to $0 \%$; depth $>1500 \mathrm{~m}, \phi=0 \%$. This analysis does not duplicate physical properties near the toe of the accretionary complex, but provides an estimate of the scale of variation in heat flow that would be likely to result from appropriate contrasts in thermal conductivity.

The simplest-case model created heat-flow variations about the mean of up to $2 \%$, insignificant when compared to the variations seen on Leg 110. Thrust faults were then modeled as discontinuities across which there was a drop in thermal conductivity (Fig. 14). The change of thermal conductivity across these faults was assumed to be $0 \%$ where the fault surface intersects the seafloor, to $15 \%$ where the thrust intersects the décollement. In this test, thermal conductivity was assumed to be 1.2 $\mathrm{W} / \mathrm{m} \cdot{ }^{\circ} \mathrm{C}$ from 0 to $40 \mathrm{~m}$ beneath the décollement and 1.4 $\mathrm{W} / \mathrm{m} \cdot{ }^{\circ} \mathrm{C}$ at greater depths (Appendix A, Site 672). We have incorporated this model of sediments near the toe of the accretionary complex into a more complete model that includes both basement topography and sediment thrust faults (Fig. 15). Heat-flow variations in these tests reached a maximum of only $4 \%$ about the mean, with the highest deviation near the deformation front. Variations in thermal conductivity are thus unlikely to contribute more than about $10 \%$ of the observed heatflow anomalies.

Bathymetry affects temperature gradients as a function of disturbance frequency and amplitude (Lachenbruch, 1968; Noel, 1984). Bathymetric variations of $10 \mathrm{~m}$ (as commonly seen near the Leg 110 drill sites) will significantly influence thermal gradients in nearby sediments but only to about 20 mbsf (Lachenbruch, 1968), affecting data collected with short outrigger probes but not the borehole measurements from Leg 110.

There is evidence of recent slumping due to slope failure on the Barbados accretionary complex, although debris flows seen on side-scan sonar are not present near the Leg 110 sites (BeIderson, et al., 1984). Slope failure at Sites 673 and 674 (Mascle, Moore et al., 1988) would result in the exposure of anomalously warm sediments in the zone of removal and rapid deposition of cooled debris over the zone of accumulation.

The process of sediment removal can be modeled as a sudden step-function drop in surface temperature. Sediment temperature as a function of depth and time is then:

$$
T(z, t)=\Delta T \operatorname{erfc}\left\{\frac{z}{2 \sqrt{\alpha t}}\right\}+g z
$$

with $T(z, t)$ measured relative to bottom-water temperature, $\Delta T$ equal to the temperature difference between bottom water and sediment, erfc being the complimentary error function (1-erf), and the other variables defined as before. 


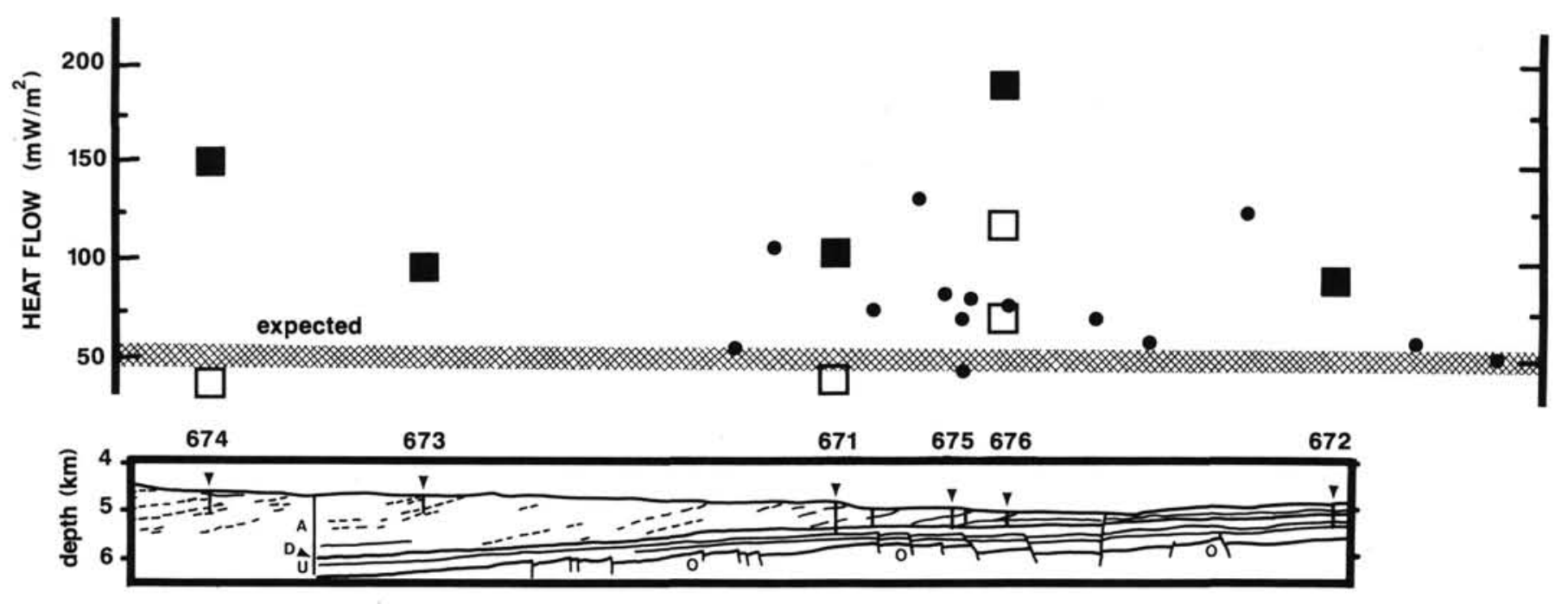

$A=$ accreted sequences $D=$ décollement $U=$ underthrust sequences $O=$ oceanic crust

Figure 13. Leg 110 heat-flow values (squares) plotted with seafloor heat-flow data from Westbrook et al. (1986) collected at $15^{\circ} 30^{\prime} \mathrm{N}$ (circles). Predicted values are based on the relations of Parsons and Sclater (1977) for heat-flow as a function of age. Data from Leg 110 have an estimated error of 10 to $15 \%$. Filled squares are "surface" heat-flow values calculated from thermal gradients forced by the temperature of bottom water at mudline. Open squares are heat flow values calculated from gradients that include at least three downhole sediment temperatures. Positions of the ODP drill sites are shown on a line drawing of multichannel seismic line CRV-128 from Moore et al. (1987).

We have assumed a background gradient of $28^{\circ} \mathrm{C} / \mathrm{km}$ (as measured between 92 and 434 mbsf at Site 674, Fig. 16A), and extrapolated this deep thermal gradient to the seafloor. This analysis estimates that the thickness of removed material $(z)$ equals $196 \mathrm{~m}$. At Site 671 extrapolation of the same background thermal gradient from the deepest temperature point to the seafloor suggests that $134 \mathrm{~m}$ of sediment has been removed. Comparisons of downhole temperature data from Sites 671 and 674 with equation (6) indicate that slump events at both sites would have had to occurred within the last 80 to $100 \mathrm{yr}$ (Figs. 16A and 16B). Slumps of this size are inconsistent with structural, lithologic, and biostratigraphic records from the drill holes (Mascle, Moore et al., 1988), which indicate no significant missing sections. In addition, the generally diffusive gradients in $\mathrm{Mg}^{++}$ and $\mathrm{Ca}^{++}$at these sites (Gieskes et al., this volume) are inconsistent with the recent removal of up to $200 \mathrm{~m}$ of sediment.

The apparent reduction in heat flow with depth at Sites 671 and 674 could be supported by fluid moving upward through the sediments (e.g., Anderson et al., 1979; Reck, 1987), but the strong $\mathrm{Mg}^{++}$and $\mathrm{Ca}^{++}$gradients and anomalous chloride and methane values (Gieskes et al., this volume) could not withstand a vertical fluid velocity of several $\mathrm{mm} / \mathrm{yr}$, as would be required by the geothermal data (Bredehoeft and Papadopoulos, 1965). The lack of significant vertical fluid flow through the sediments is consistent with numerical studies of the Barbados accretionary complex that suggest average permeability values of about $10^{-18} \mathrm{~m}^{2}$ (Wuthrich et al., 1987 and this volume; Taylor and Leonard, this volume).

\section{Fluid Flow Along Conduits}

\section{Site 672}

Geochemical, structural, and thermal observations suggest that water is flowing laterally through the prism in conduits located at structural and lithologic discontinuities (Moore et al., 1987). Reference Site 672 was intended to provide a baseline to which the other Leg 110 sites could be compared. Although the surface heat flow at Site 672 is the lowest measured on Leg 110 $\left(92 \mathrm{~mW} / \mathrm{m}^{2}\right)$, it is still $80 \%$ higher than expected for $90 \mathrm{Ma}$ crust. Either the entire sedimentary section is anomalously warm, requiring a heat source in the underlying plate, or there is a heat source within the sediments at a depth greater than 134 mbsf (that of the deepest temperature measurement).

One likely source of extra heat is warm fluid moving along a more porous "proto-décollement" zone centered at $190 \mathrm{mbsf}$ (Moore et al., 1987; Moran and Christian, this volume) or one of the sand layers encountered at 370 and 450 mbsf. All these horizons correlate with chloride minima and methane maxima (Moore et al., 1987; Gieskes et al., this volume).

If fluid flowing through the high-porosity zone at $190 \mathrm{mbsf}$ is to account for the large thermal gradient observed in the upper $134 \mathrm{~m}$, then that fluid temperature must be at about $17^{\circ} \mathrm{C}$. To maintain a gradient of $79^{\circ} \mathrm{C} / \mathrm{km}$ without fluid flow higher in the section, the uppermost sand layer at 370 mbsf would have a temperature of about $31^{\circ} \mathrm{C}$ and the basement surface would be at about $65^{\circ} \mathrm{C}$. The four-fold variation in thermal gradients within measurement intervals at Site 672 suggests that there may be minor lateral flow at other levels or a small component of upward flow as well.

\section{Site 671}

High gradients just below the seafloor at Sites 671, 673, and 674 also require shallow heat sources. At Site 671 , horizontal flow of warm fluid between 36 and 168 mbsf could cause the observed break in the thermal gradient, although there may be additional heat sources at greater depth. Likely conduits include the major thrusts identified at 115,380 , and $460 \mathrm{mbsf}$, the décollement zone between 500 and 530 mbsf, and the sand layers below 680 mbsf.

There is a small chloride anomaly at Site 671 , at $113 \mathrm{mbsf}$ (Gieskes et al., this volume) suggesting flow of fresh fluids along the shallowest thrust at 115 mbsf. However, extrapolation of the surface thermal gradient $\left(105^{\circ} \mathrm{C} / \mathrm{km}\right)$ to $113 \mathrm{mbsf}$ yields a sediment temperature $>14.2^{\circ} \mathrm{C}$, greater than that measured at $168 \mathrm{mbsf}\left(10.7^{\circ} \mathrm{C}\right)$. If warm fluid flow is responsible for the large surface thermal gradient at Site 671, this flow might have 


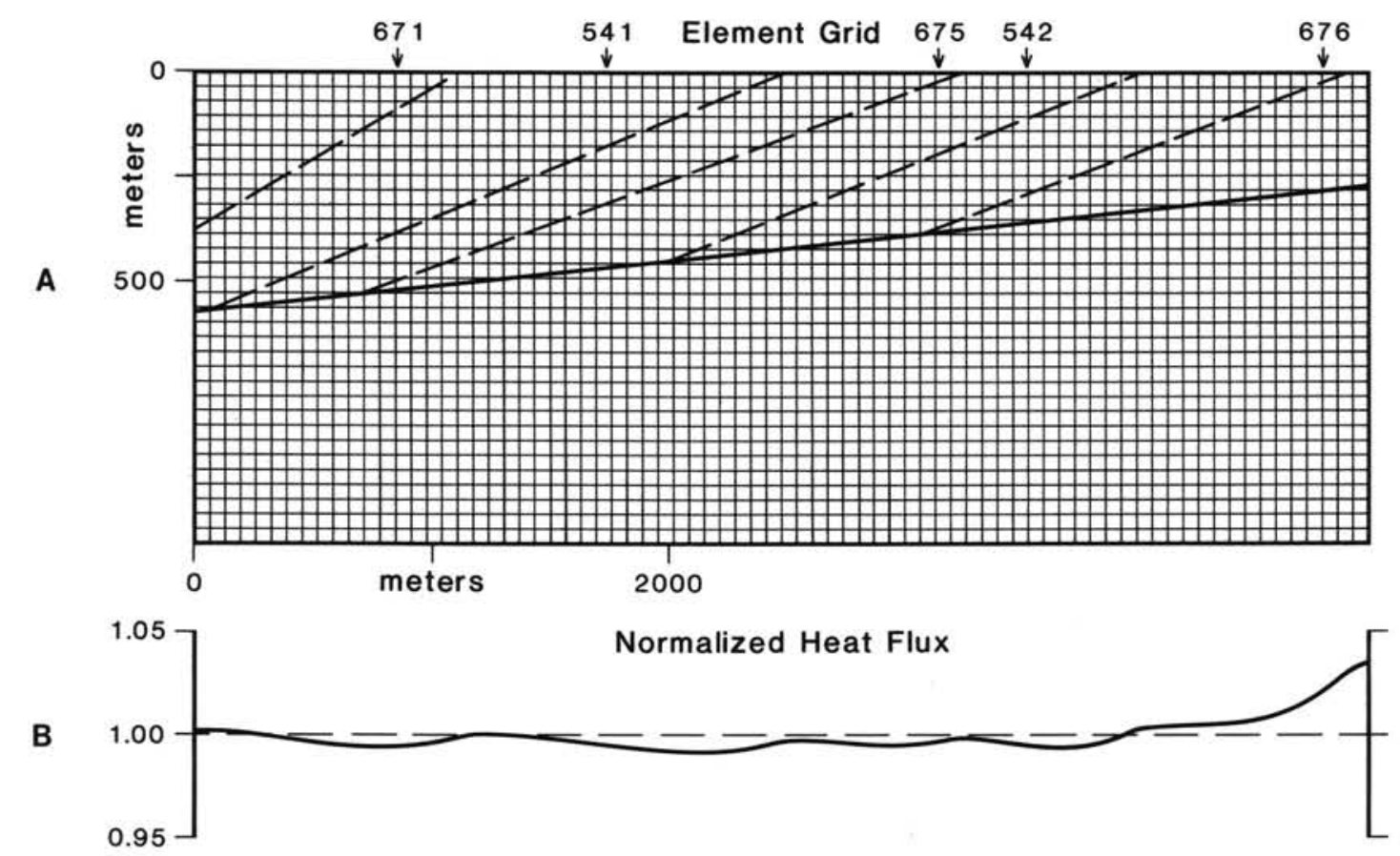

Thermal Conductivity

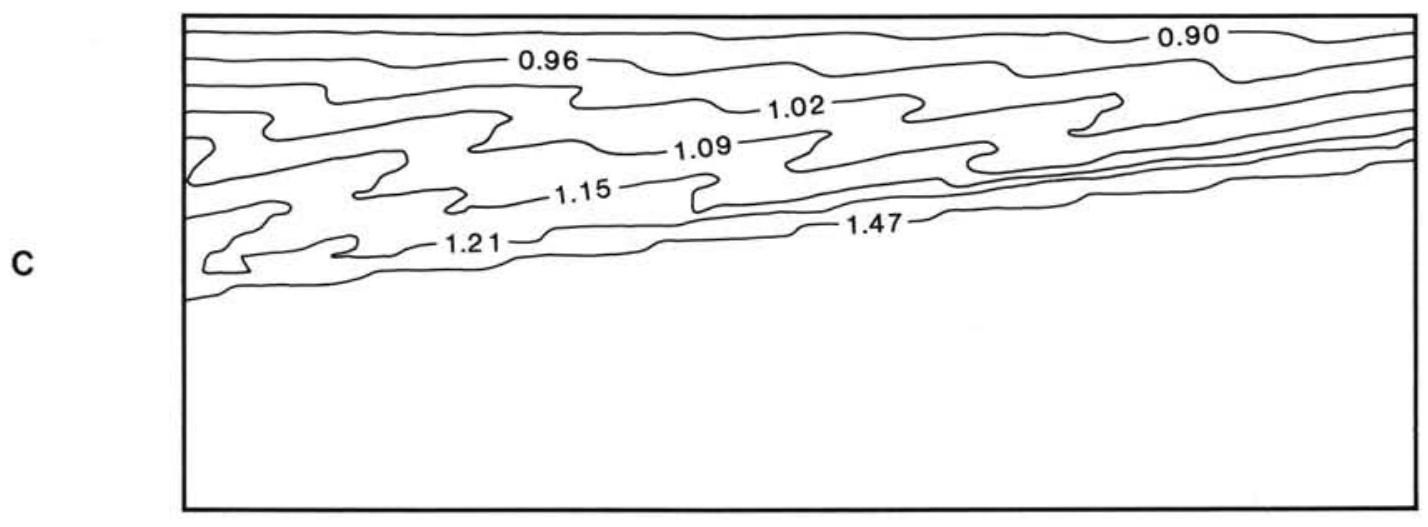

$\mathrm{W} / \mathrm{m} \cdot{ }^{\circ} \mathrm{C}$

Figure 14. Configuration and results of a finite-difference model to test the effects of sloping thermal conductivity surfaces on heat flow. (A) Modeling grid showing locations of ODP and DSDP drill sites, the décollement horizon and five thrusts through the accretionary complex. (B) Surface heat-flow variation about normalized values as a result of thermal conductivity contrasts. (C) Thermal conductivity structure of the prism. Thermal conductivity is related directly to porosity with a three-layer porosity model. Thermal conductivity was also assumed to decrease below thrusts as sediments of different ages are juxtoposed and as a result of sediment compaction and dewatering.

been stopped long enough to allow partial thermal reequilibration.

If we assume a background gradient of $36^{\circ} \mathrm{C} / \mathrm{km}$ at Site 671 (as measured between 36 and $168 \mathrm{mbsf}$ ) then by extrapolating downward from the deepest temperature measurement $\left(10.7^{\circ} \mathrm{C}\right.$ at $168 \mathrm{mbsf}$ ), a temperature of about $22.5^{\circ} \mathrm{C}$ is predicted at the décollement. A similar calculation at Site 676 yields a temperature at the décollement of about $22.2^{\circ} \mathrm{C}(280 \mathrm{mbsf})$. Higher projected temperatures at the décollement beneath Sites $673\left(66^{\circ} \mathrm{C}\right.$, $1100 \mathrm{mbsf})$ and $674\left(49^{\circ} \mathrm{C}, 1500 \mathrm{mbsf}\right)$ may be unrealistic. These last two values, in combination with a higher projected temperature at Site 673 when compared to Site 674 , suggest that there may be additional changes in the thermal gradient below the deepest measurements at one or both of these sites.

\section{Site 674}

Likely fluid conduits at Site 674 include a high-porosity zone at 60 to 70 mbsf and thrusts at 100 and 250 mbsf. A break in thermal gradient between 26 and 92 mbsf correlates with a chloride anomaly suggesting migration of low-salinity water along a high-porosity zone (Gieskes et al., this volume). A consistent thermal gradient below 92 mbsf (Fig. 6) indicates that if flow is occurring between 92 and 440 mbsf (as is suggested by the presence of chloride anomalies at 100 and 250 mbsf; Gieskes et al., this volume) then these fluids are at nearly the same temperature as the surrounding sediments. More likely, flow along these thrusts has ceased for long enough to allow full thermal reequilibration of the sediments (several hundred years). However, 

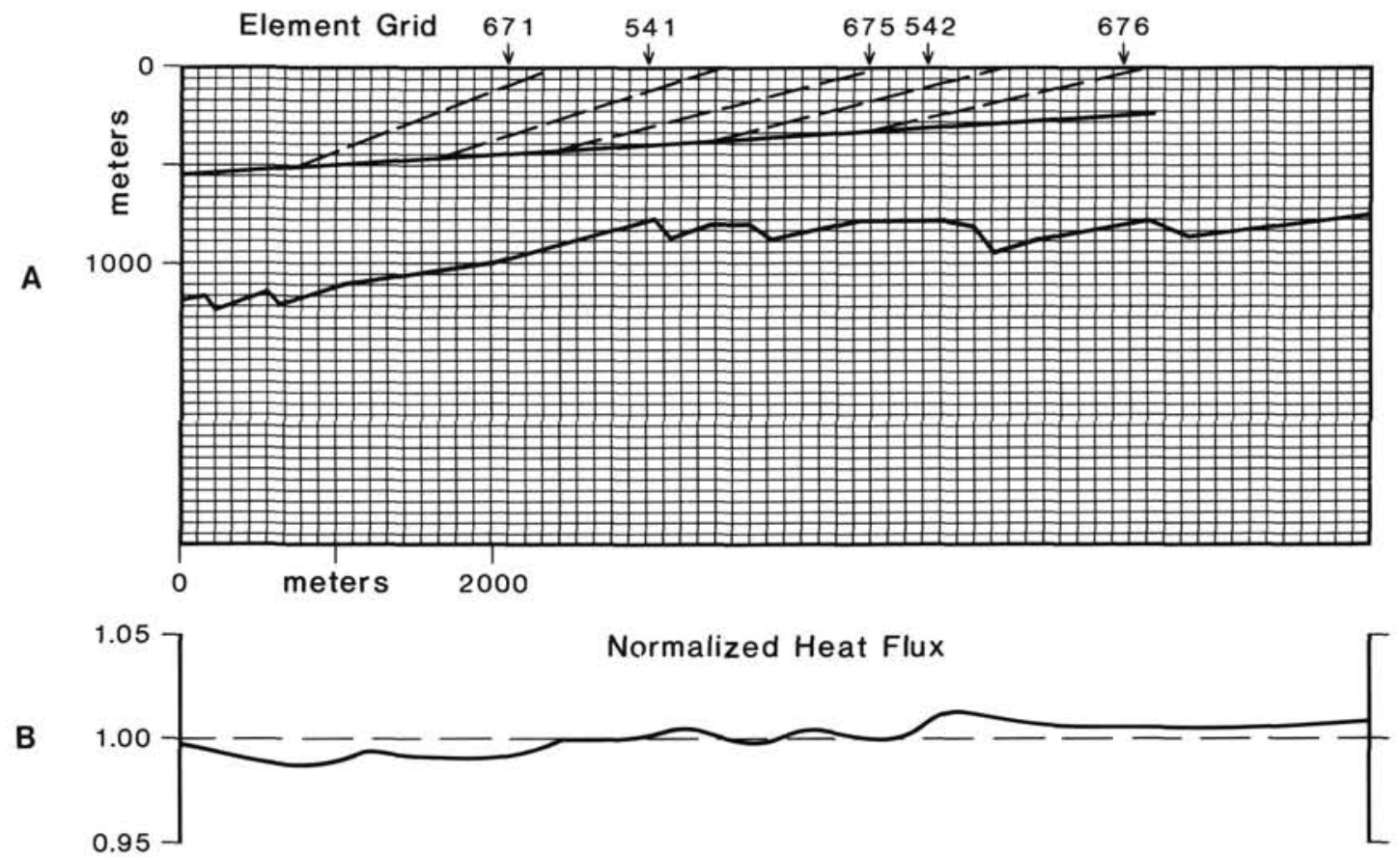

Thermal Conductivity

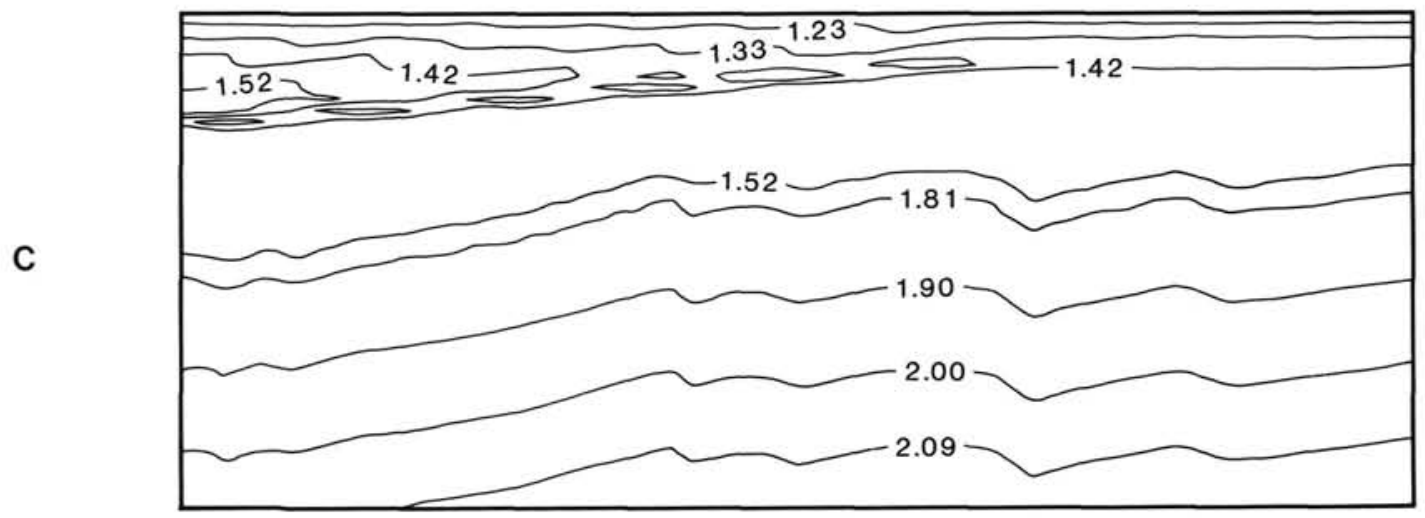

$\mathbf{W} / \mathrm{m} \cdot{ }^{\cdot \mathrm{C}}$

Figure 15. Modified version of the model in Figure 14, including basement topography. Surface heat flow varies by a maximum of $4 \%$ about normalized values in both Figures 14 and 15.

flow must have been active within the last thousands to tens of thousands of years to account for the observed geochemical anomalies. It is impossible to better constrain the timing of flow because we do not know the duration or intensity of the original geochemical and geothermal signals.

Fluid flowing along the high-porosity zone between 60 and 70 mbsf requires a temperature of about $10.3^{\circ} \mathrm{C}$ (equal to that measured at $92 \mathrm{mbsf}$ ) to maintain a surface gradient of $135^{\circ} \mathrm{C} /$ $\mathrm{km}$. Temperatures at 60 to $70 \mathrm{mbsf}$ are thus probably lower; a small slump or some component of upward flow may contribute to the high thermal gradient at the surface. Alternatively, horizontal flow at 60 to 70 mbsf may have stopped in the last 10 to $50 \mathrm{yr}$, allowing some equilibration of the sediments.

\section{Site 676}

The thermal data from Site 676 require a more complex explanation. The propagating thrust penetrated at approximately 30 mbsf was accompanied by a methane anomaly (Gieskes et al., this volume), and correlated with a change from a positive to a negative geothermal gradient. Another methane anomaly at approximately $70 \mathrm{mbsf}$ correlates with another break in geothermal gradient. The only way to maintain a steady-state $182^{\circ} \mathrm{C} /$ $\mathrm{km}$ gradient at the surface and a geothermal inversion below is to have at least three distinct temperature (fluid flow) surfaces at 30,65 , and 100 mbsf.

A more likely explanation is that the thermal inversion at Site 676 is transient. The thermal gradient between 64 and 102 mbsf is nearly colinear with bottom water (Fig. 7), suggesting that there may have been a time when there was flow of $11.5^{\circ} \mathrm{C}$ fluid along a conduit near 102 mbsf maintaining a surface gradient of $92^{\circ} \mathrm{C} / \mathrm{km}$, but no lateral flow at shallower depths. A steady-state gradient of approximately $60^{\circ} \mathrm{C} / \mathrm{km}$ below 102 mbsf requires an additional temperature surface at greater depth (for example, about $20^{\circ} \mathrm{C}$ at $250 \mathrm{mbsf}$ ). Assuming this state as an initial condition, we have calculated the thermal effects of introducing flow along a second conduit at approximately 33 mbsf (the depth of intersection of the surface gradient, $182^{\circ} \mathrm{C} /$ $\mathrm{km}$, and the reversed gradient, $-11^{\circ} \mathrm{C} / \mathrm{km}$ ). This model re- 
A

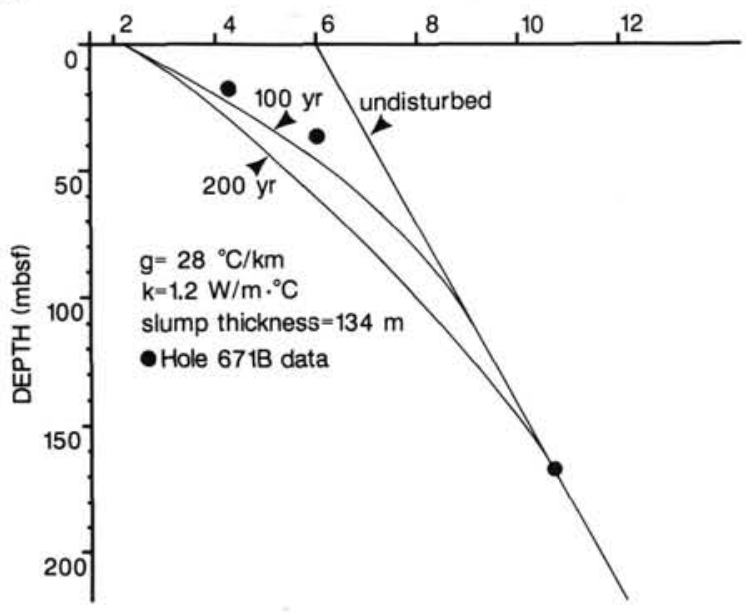

B TEMPERATURE $\left({ }^{\circ} \mathrm{C}\right)$

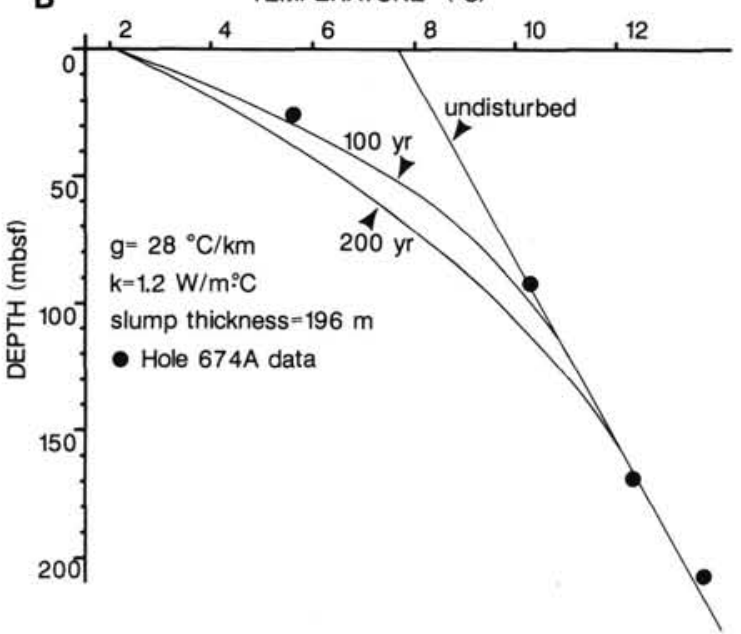

Figure 16. Results of models of the thermal effects of large sediment slumps over Sites 671 and 674 . The initial background thermal gradient was assumed to be $28^{\circ} \mathrm{C} / \mathrm{km}$, as measured at Site 674 from 92 to 434 mbsf. The slumps were modeled as sudden drops in bottom-water temperature. (A) At Site 674 , the projected initial temperature was $7.71^{\circ} \mathrm{C}$, requiring the removal of $196 \mathrm{~m}$ of sediment. The curves show temperature profiles after 0,100 , and 200 years. (B) At Site 671 , the projected initial sediment temperature before the slump was $6.01^{\circ} \mathrm{C}$, requiring the removal of $134 \mathrm{~m}$ of sediment. In both cases, the slump events would had to have occured within the last 80 to $100 \mathrm{yr}$ to explain the observed sediment temperatures.

quires fluid flow along just two surfaces (instead of three, as required in the steady-state case), and provides the most reasonable explanation for the sediment temperatures observed at Site 676.

The thermal gradient through a slab of material bounded by fixed temperature surfaces was calculated by solving the one-dimensional heat-flow equation:

$$
\frac{\partial T}{\partial t}=\alpha \frac{\partial^{2} T}{\partial z^{2}}
$$

with the following boundary and initial conditions:

$$
T(0, t)=T_{0}, T(L, t)=T_{L}, T(z, 0)=\mathcal{F}(z)
$$

where $\mathrm{L}$ is the thickness of the layer of interest. The combination of equations (7) and (8) have the following solution (Carslaw and Jaeger, 1959; p. 100):

$$
\begin{aligned}
T(z, t)= & T_{0}+\left(T_{0}+T_{L}\right)+ \\
& \frac{2}{\pi} \sum_{n=1}^{\infty} C \frac{T_{0} \cos n \pi-T_{L}}{n}+ \\
& \frac{2}{L} \sum_{n=1}^{\infty} C \int_{0}^{L} \mathcal{F}\left(z^{\prime}\right) \sin \frac{n \pi z^{\prime}}{L} d z^{\prime}
\end{aligned}
$$

where

$$
C=\sin \frac{n \pi z}{L} \exp \frac{-\alpha n^{2} \pi^{2} t}{L^{2}}
$$

If the original thermal gradient is linear, $F(z)=T_{1}+g z, 0$ $<z<L$, the integral in the last term above can be solved analytically:

$$
\begin{array}{cc}
\int_{0}^{L}\left(T_{1}+g z\right) \sin \frac{n \pi z^{\prime}}{L} d z^{\prime}= \\
\frac{L}{n \pi}\left(2 T_{1}+g L\right) & \text { for } n \text { odd } \\
\frac{-g L^{2}}{n \pi} & \text { for } n \text { even. }
\end{array}
$$

Our model assumed an initially linear thermal gradient of $92^{\circ} \mathrm{C} / \mathrm{km}$ from the surface to $102 \mathrm{mbsf}$. An additional temperature surface (representing later fluid flow) was then introduced within this interval. A range of temperatures from 8.2 to $8.7^{\circ} \mathrm{C}$ and a range of flow depths from 30 to 35 mbsf yielded similar results. Sediment temperatures were calculated over the interval using equations (9) and (10).

One set of calculations is presented in Figure 17 along with downhole temperature data from Hole 676A. These results indicate that flow along this latest conduit began within the last 10 to $20 \mathrm{yr}$.

\section{Site 673}

There is also evidence for transient flow at Site 673, where although heat-flow results are inadequate to differentiate between a linear and a non-linear thermal gradient, chloride anomalies (Gieskes et al., this volume) probably resulted from fluid flow at a time sufficiently long ago for an associated temperature disturbance to decay (greater than about $100 \mathrm{yr}$ ).

At Site 673, the most likely horizons for fluid flow are major thrusts at 90,200, and 290 mbsf. The décollement is approximately $1100 \mathrm{mbsf}$ and would need to contain fluid with a temperature $>66^{\circ} \mathrm{C}$ to maintain a geothermal gradient of $60^{\circ} \mathrm{C} /$ $\mathrm{km}$, as measured between 27 and 75 mbsf in Hole 673B. Chloride anomalies with peaks at 200 and 290 mbsf suggest flow along these correlated thrusts. If the $60^{\circ} \mathrm{C} / \mathrm{km}$ gradient is extrapolated to these depths, temperatures of 14.8 and $20.2^{\circ} \mathrm{C}$ are predicted.

Simple calculations based on thermal gradients and heat flow data from Leg 110 are thus consistent with transient fluid flow along high-permeability conduits within the sediments, starting and stopping over intervals of tens to tens of thousands of years. This process makes intuitive sense because a constantpressure head could probably not be maintained were there to be constant flow at shallow depths through the accretionary complex. The venting of water from a number of exit points near the deformation front on time scales of tens to hundreds of 
TEMPERATURE $\left({ }^{\circ} \mathrm{C}\right)$

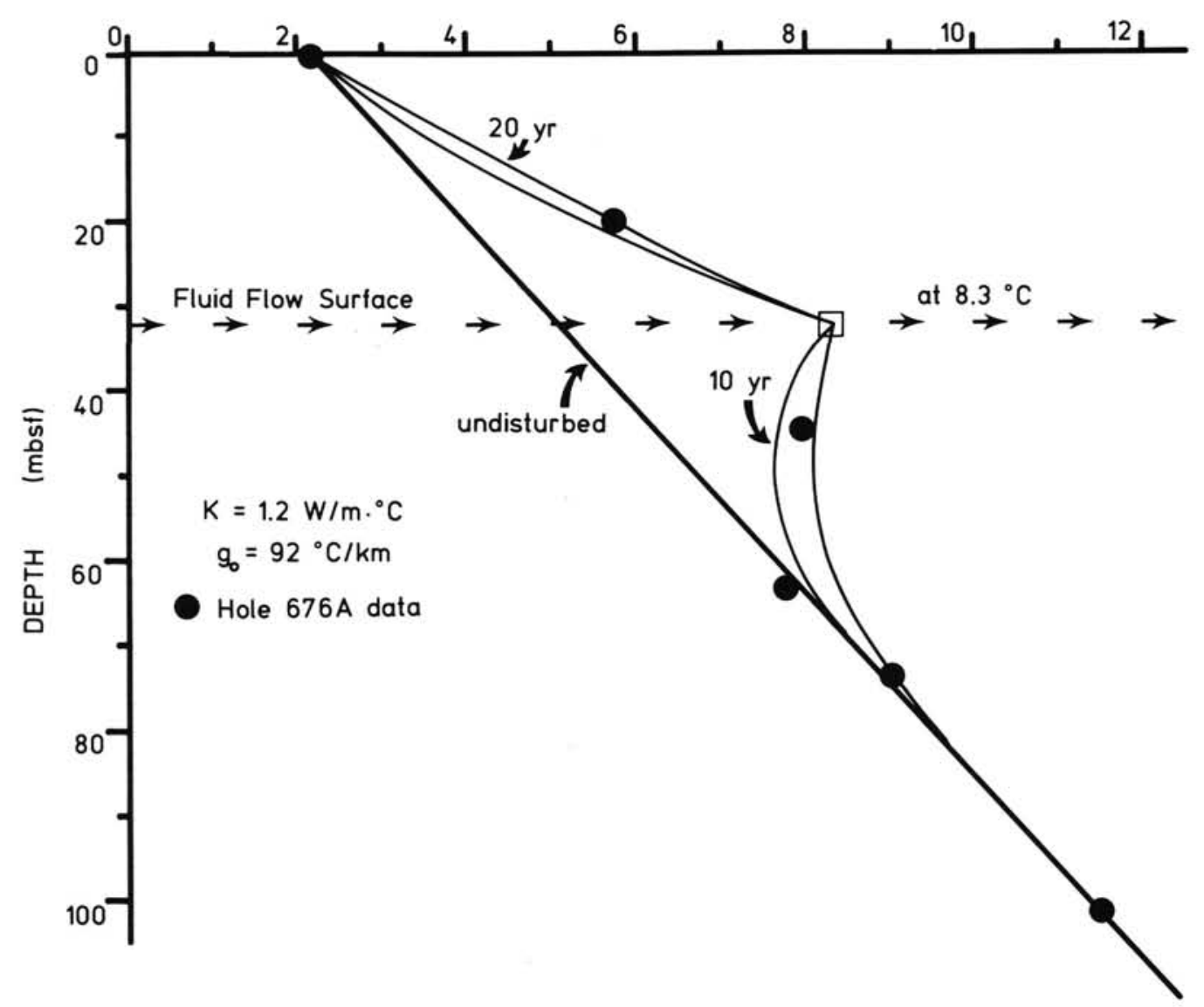

Figure 17. Results of a transient model to produce the observed sediment temperatures at Site 676 . It was assumed that the thermal conductivity was $1.2 \mathrm{~W} / \mathrm{m}^{\circ} \mathrm{C}$, and that there were constant-temperature surfaces at $0.0\left(2.14^{\circ} \mathrm{C}\right)$ and 102 mbsf $\left(11.5^{\circ} \mathrm{C}\right)$. These conditions would result in a steady-state conductive thermal gradient of $92^{\circ} \mathrm{C} / \mathrm{km}$. Another constant-temperature (fluid flow) surface was then introduced at $32 \mathrm{mbsf}$ at $8.3^{\circ} \mathrm{C}$. Sediment temperatures were calculated as a function of depth and time according to equations (9) and (10). The downhole temperature data from Hole 676A are plotted for comparison. The good agreement suggests that flow at about 32 mbsf began 10 to $20 \mathrm{yr}$ ago. Changing the depth of flow or the flow temperature within a range bracketed by the downhole data yields results with similar time scales for fluid flow.

years (as proposed here for the toe of the prism) is also compatible with previous studies of surface heat flow (Westbrook et al., 1986; Langseth et al., 1988).

\section{SUMMARY AND CONCLUSIONS}

The seafloor heat flow values measured at $15^{\circ} 30^{\prime} \mathrm{N}$ on ODP Leg 110 and by Westbrook et al. (1986) are generally higher than: (1) values predicted based on the age of the underlying oceanic crust; (2) values expected based on theoretical models of convergent margins; and (3) values measured previously along the deformation front of the Barbados accretionary complex at other latitudes. The thermal anomalies detected on Leg 110 include not only the toe of the accretionary complex, but also reference Site $672,6 \mathrm{~km}$ east of the deformation front. Geothermal data from all five sites are consistent with the flow of warm fluids along sub-horizontal conduits both landward and seaward of the deformation front. The temperature of fluids within or below the décollement (marked by chloride and methane anomalies) is at least $20^{\circ} \mathrm{C}$, based on data from Sites 671,672 , and 676 . Fluids that raise surface thermal gradients at Sites 673 and 674 are more troublesome to characterize because there is greater uncertainty as to their depth of flow.

It is difficult to determine the depth of origin for these fluids because we have no good estimate of either the true background thermal gradient or background heat flow through the toe of the accretionary complex. The oceanic reference site, which was intended to provide this baseline information, proved to be nearly as anomalous as the sites west of the deformation front. The deep geothermal gradient of $28^{\circ} \mathrm{C} / \mathrm{km}$ at Site 674 cannot be considered as a typical accretionary complex value, as it is influenced by rapid heat advection along one or more conduits.

Any explanation for the high, and highly variable, heat flow measured downhole and near the surface at $15^{\circ} 30^{\prime} \mathrm{N}$ should also account for the lack of apparent anomalies elsewhere along the toe of the accretionary complex. If the high values are due to expulsion of pore water from the prism, then the drill sites may be located over a discharge zone, with dewatering more active here than elsewhere along the complex. Fluid discharge may be favored on the flank of the Tiburon Rise due to (1) relatively thin sediment cover between $15^{\circ}$ and $16^{\circ} 10^{\prime} \mathrm{N}$; (2) the extreme westerly extent of the deformation front (Mauffret et al., 1984); and (3) the high elevation of the Tiburon rise where it crosses the deformation front (Mauffret et al., 1984).

The mechanisms and expressions of sediment compaction, alteration, and dewatering may vary continuously along strike of the deformation front. These variations probably allow for ubiquitous fluid flow in some zones, formation of "rough grounds" and mud volcanoes in others (e.g., Langseth et al., 
1988), and isolated discharge in still others. Only further drilling, coring, and testing will establish whether the DSDP and ODP drill sites transect sampled sections that are truly anomalous or representative of the Barbados accretionary complex.

\section{ACKNOWLEDGMENTS}

Thanks to Captain Ed Oonk and the officers and crew of the JOIDES Resolution for their considerable assistance during Leg 110. We also thank the lab officers and technicians for their help in data collection. We are grateful to ODP Cruise Operations Manager, Lamar Hayes, and the outstanding SEDCO crew who penetrated the décollement on the first try and maintained good hole conditions so that downhole measurements could be made. Physical properties specialists Pat McLellan, Kate Moran, Elliott Taylor, and Roy Wilkens performed the thermal conductivity measurements. Co-chief scientists J. Casey Moore and Alain Mascle and ODP staff scientist Elliott Taylor devoted valuable ship time to downhole experiments and were always encouraging. Mark Langseth and Michael Hobart kindly provided figures with data from the 1985 heat-flow survey of the deformation front. This research was supported by National Science Foundation Grant OCE 85-135337, a United States Science Program Grant, two Houston Underwater Club SEASPACE Scholarships, Grants-in-Aid from Sigma Xi, the American Association of Petroleum Geologists, and the Southeastern Section of the Geological Society of America (A.F.) and by a grant from the Natural Environment Resource Council (M.H.). This manuscript benefited from discussions with Keir Becker and helpful reviews by Mark Langseth and Larry Lawver.

\section{REFERENCES}

Abbott, D. H., Hobart, M. A., and Embley, R. W., 1986. Heat flow and mass wasting in the Wilmington Canyon region, U.S. continental margin. Geo-Mar. Lett., 6:131-138.

Anderson, R. N., Hobart, M. A., and Langseth, M. G., 1979. Geothermal convection through ocean crust and sediments in the Indian Ocean. Science, 204:828-832.

Belderson, R. H., Denyon, N. H., and Stride, A. H., 1984. Morphology and structural trends of the Barbados ridge complex in the vicinity of Deep Sea Drilling Project Sites 541, 542 and 543, as revealed by Gloria long-range side-scan sonar, In Biju-Duval, B., Moore, J. C., et al., Init. Repts. DSDP, 78A: Washington (U.S. Govt. Printing Office), 79-81.

Biju-Duval, B., Moore, J. C., et al., 1984. Init. Repts. DSDP, 78A: Washington (U.S. Govt. Printing Office).

Bray, C. J., and Karig, D. D., 1985. Porosity of sediments in accretionary prisms and some implications for dewatering processes. J. Geophys. Res., 90: 768-776.

Bredehoeft, J. D., and Papadopoulos, I. S., 1965. Rates of vertical groundwater movement estimated from the earth's thermal profile. Water Resour. Res. 1:325-328.

Bullard, E. C., 1939. Heat flow in South Africa. Proc. R. Soc. London, Ser. A173:474-502.

1954. The flow of heat through the floor of the Atlantic Ocean. Proc. R. Soc. London, Ser. A222:408-429.

Bullard, E. C., and Day, A., 1961. The heat flow through the floor of the Atlantic. Geophys. J. R. Astron. Soc., 4:282-292.

Burch, T. K., and Langseth, M. G., 1981. Heat flow determination in three DSDP boreholes near the Japan Trench. J. Geophys. Res. 86: 9411-9419.

Cande, S. C., Leslie, R. B., Parra, J. C., and Hobart, M. A., 1987. Interaction between the Chile ridge and Chile trench: geophysical and geothermal evidence. J. Geophys. Res., 92:495-520.

Carslaw, H. S., and Jaeger, J. C., 1959. Conduction of Heat in Solids: New York (Oxford University Press).

Chapman, D. C., Howell, J., and Sass, J. H., 1984. A note on drillhole depths required for reliable heat flow determinations. Tectonophysics, 103:11-18.

Davis, D. M. and Hussong, D. M., 1984. Geothermal observations during Deep Sea Drilling Project Leg 78A. In Biju-Duval, B., Moore, J. C., et al., Init. Repts. DSDP, 78A: Washington (U.S. Govt. Printing Office), 593-598.

Donnelly, T., Francheteau, J., et al., 1980. Init. Repts. DSDP, 51, 52, and 53: Washington (U.S. Govt. Printing Office).
Hamilton, E. L., 1976. Variations of density and porosity with depth in deep sea sediments. J. Sediment. Petrol., 46:280-300.

Horai, K., and Von Herzen, R. P., 1985. Measurement of heat flow on Leg 86 of the Deep Sea Drilling Project. In Heath, G. R., Burckle, L. H., et al., Init. Repts. DSDP, 86: Washington (U.S. Govt. Printing Office), 759-777.

Hsui, A. T., and Toksoz, M. N., 1979. The evolution of thermal structures beneath a subduction zone, Tectonophysics, 60:43-60.

Hyndman, R. D., and Drury, M. J., 1976. The physical properties of oceanic basement rocks from deep sea drilling on the Mid-Atlantic Ridge. J. Geophys. Res., 81:4042-4052.

Koehler, R., and Von Herzen, R. P., 1986. A miniature deep sea temperature data recorder: design, construction, and use. Tech. Rep. WHOI-86, Woods Hole Oceanographic Institution.

Kulm, L. D., Suess, E., Moore, J. C., Carson, B., Lewis, B. T., Ritger, S. D., Kadko, D. C., Thornberg, T. M., Embley, R. W., Rugh, W. D., Massoth, G. L., Langseth, M. G., Cochran, G. R., and Scamman, R. L., 1986. Oregon subduction zone: venting fauna and carbonates. Science, 231:561-566.

Langseth, M. G., and Burch, T., 1980. Geothermal observations of the Japan Trench transect. In Langseth, M. G., Okada, H., et al., Init. Repts. DSDP, 56, Pt. 2: Washington (U.S. Govt. Printing Office), 1207-1210.

Langseth, M. G., Hobart, M. A., and Horai K., 1980. Heat flow in the Bering Sea. J. Geophys. Res., 85:3740-3752.

Langseth, M. G., Westbrook, G. K., and Hobart, M. A., 1988. Geophysical surveys of a mud volcano seaward of the Barbados accretionary complex. J. Geophys. Res., 93:1049-1061.

Lachenbruch, A. M., 1968. Rapid estimation of the topographic disturbance to superficial thermal gradients. Rev. Geophys., 6:365-400.

Mascle, A., Moore, J. C., et al., 1988. Proc. ODP, Init. Repts., 110: College Station, TX (Ocean Drilling Program.

Mauffret, A., Westbrook, G., Truchan, K., and Ladd, J., 1984. The relief of oceanic basement and the structure of the front of the accretionary complex in the region of Sites 541,542 and 543. In BijuDuval, B., Moore, J. C., et al., Init. Repts. DSDP, 78A: Washington (U.S. Govt. Printing Office), 49-56.

Moore, J. C., Mascle, A., Taylor, E., and the ODP Leg 110 Scientific Party, 1987. Expulsion of fluids from depth along a subduction zone decollement horizon. Nature, 326:785-788.

Morin, R., and Silva, A. J., 1984. The effects of high pressure and high temperture on some physical properties of ocean sediments. J. Geophys. Res., 89:511-526.

Morin, R., and Von Herzen, R. P., 1986. Geothermal measurements at Deep Sea Drilling Project Site 587. In Kennett, J. P., von der Borch, C. C., et al., Init. Repts. DSDP, 90, Pt. 2: Washington (U.S. Govt. Printing Office), $1317-1324$.

Noel, M., 1984. Origins and significance of non-linear temperature profiles in deep sea sediments. Geophys. J. R. Astron. Soc. 76:673-690.

Parsons, B. and Sclater, J. G., 1977. An analysis of the variation of ocean floor bathymetry and heat flow with age. J. Geophys. Res., $82: 802-827$.

Ratcliffe, E. H., 1960. The thermal conductivities of ocean sediments. J. Geophys. Res., 65:1535-1541.

Reck, B. H., 1987. Implication of measured thermal gradients for water movement through the northeast Japan accretionary complex. $J$. Geophys. Res. 92:3683-3690.

Sclater, J. G., Jaupart, C., and Galson, D., 1980. The heat flow through oceanic and continental crust and the heat loss of the earth. Rev. Geophys. Space Phys., 18:269-311.

Sclater, J. G., Jones, E.J.W., and Miller, S. P., 1970. The relationship of heat flow, bottom topography and basement relief in Peak and Freen Deeps, northeast Atlantic. Tectonophysics, 10:288-300.

Shi, Y., and Wang, C., 1985. High pore pressure generation in sediments in front of the Barbados Ridge complex. Geophys. Res. Lett., 12:773-776.

Von Herzen, R. P., and Maxwell, A. E., 1959. The measurement of thermal conductivity of deep-sea sediments by a needle-probe method. J. Geophys. Res. 64:1557-1563.

Watanabe, T., Langseth, M. G., and Anderson, R. N., 1977. Heat flow in back-arc basins of the western Pacific. In Talwani, M., and Pitman, W. C., III (Eds.), Island arcs, deep sea trenches, and back-arc basins. Maurice Ewing Series 1: Washington (Am. Geophys. Union), 137-161. 
WestBrook, G. K., Langseth, M. G., and Hobart, M. A., 1986. Geothermal observations over the seaward edge of the Barbados Ridge Accretionary Prism, EOOS, 68:1218. (Abstract)

Whitmarch, R. B., 1979. Seismic refraction studies of the upper igneous crust in the North Atlantic and porosity estimates for Layer 2. Earth Planet. Sci. Lett., 37:451-464.

Wuthrich, D. R., Screaton, E. J., and Dreiss, S., 1987. A model of fluid flow and pore pressures for the Lesser Antilles accretionary complex. Eos, 68:1486. (Abstract)
Yamano, M., Honda, S., and Uyeda S., 1984. Nankai Trough: A hot trench? Mar. Geophys. Res., 6:187-203.

Yokata, T., Kinoshita, H., and Uyeda, S., 1980. New DSDP downhole temperature probe utilizing ICRAM (Memory) elements. Bull. Earthquake Res. Inst., 55:77-88.

Date of initial receipt: 8 February 1988

Date of acceptance: 20 April 1989

Ms 110B-154 
APPENDIX A

Summary of thermal conductivity data and corrections for each hole. $K_{u}$ and $K_{c}$ are uncorrected and corrected thermal conductivity values, respectively; $\phi$ is porosity.

\begin{tabular}{|c|c|c|c|c|c|}
\hline \multirow[b]{2}{*}{$\begin{array}{l}\text { Depth } \\
\text { (mbsf) }\end{array}$} & \multirow[b]{2}{*}{$\begin{array}{c}K_{u} \\
\left(\mathrm{~W} / \mathrm{m} \cdot \cdot{ }^{\circ} \mathrm{C}\right)\end{array}$} & \multirow[b]{2}{*}{$\phi$} & \multicolumn{2}{|c|}{ Corrections } & \multirow[b]{2}{*}{$\begin{array}{c}K_{\mathrm{c}} \\
\left(\mathrm{W} / \mathrm{m} \cdot{ }^{\circ} \mathrm{C}\right)\end{array}$} \\
\hline & & & $\begin{array}{c}\text { pressure } \\
(\%)\end{array}$ & $\begin{array}{c}\text { temperature } \\
(\%)\end{array}$ & \\
\hline \multicolumn{6}{|l|}{ Hole 671B } \\
\hline 2.20 & 1.07 & 77.40 & 2.50 & -4.15 & 1.05 \\
\hline 3.70 & 1.05 & 75.00 & 2.38 & -4.11 & 1.04 \\
\hline 9.60 & 1.08 & 73.30 & 2.23 & -3.98 & 1.06 \\
\hline 12.60 & 1.02 & 76.30 & 2.56 & -3.92 & 1.00 \\
\hline 19.10 & 1.14 & 70.30 & 1.94 & -3.78 & 1.12 \\
\hline 22.60 & 1.18 & 66.80 & 1.69 & -3.72 & 1.16 \\
\hline 24.60 & 1.16 & 68.70 & 1.83 & -3.68 & 1.14 \\
\hline 28.60 & 1.06 & 73.60 & 2.30 & -3.61 & 1.04 \\
\hline 31.60 & 1.20 & 68.40 & 1.76 & -3.56 & 1.17 \\
\hline 34.60 & 1.21 & 64.80 & 1.57 & -3.51 & 1.19 \\
\hline 38.10 & 1.20 & 70.30 & 1.85 & -3.46 & 1.18 \\
\hline 41.10 & 1.18 & 68.00 & 1.77 & -3.44 & 1.16 \\
\hline 47.80 & 1.02 & 59.40 & 1.57 & -3.40 & 1.01 \\
\hline 50.80 & 1.20 & 63.00 & 1.50 & -3.37 & 1.18 \\
\hline 53.80 & 1.15 & 67.70 & 1.80 & -3.35 & 1.13 \\
\hline 57.10 & 1.26 & 68.80 & 1.70 & -3.33 & 1.24 \\
\hline 60.10 & 1.21 & 61.90 & 1.44 & -3.31 & 1.19 \\
\hline 63.10 & 1.34 & 59.00 & 1.18 & -3.29 & 1.31 \\
\hline 66.60 & 1.25 & 61.20 & 1.35 & -3.27 & 1.23 \\
\hline 69.60 & 1.28 & 63.40 & 1.43 & -3.24 & 1.25 \\
\hline 72.60 & 1.07 & 61.90 & 1.64 & -3.22 & 1.05 \\
\hline 79.10 & 1.35 & 58.70 & 1.17 & -3.18 & 1.32 \\
\hline 82.10 & 1.33 & 58.50 & 1.18 & -3.16 & 1.30 \\
\hline 86.05 & 1.03 & 61.70 & 1.70 & -3.13 & 1.01 \\
\hline 87.55 & 1.15 & 59.00 & 1.39 & -3.12 & 1.13 \\
\hline 89.05 & 1.23 & 58.70 & 1.28 & -3.11 & 1.21 \\
\hline 93.80 & 1.50 & 63.50 & 1.23 & -3.08 & 1.48 \\
\hline 96.80 & 1.37 & 65.20 & 1.42 & -3.06 & 1.35 \\
\hline 99.80 & 1.37 & 57.20 & 1.10 & -3.04 & 1.34 \\
\hline 102.75 & 1.20 & 58.10 & 1.30 & -3.02 & 1.17 \\
\hline 104.25 & 1.06 & 56.40 & 1.39 & -3.00 & 1.04 \\
\hline 105.75 & 1.13 & 59.80 & 1.45 & -2.99 & 1.11 \\
\hline 112.25 & 0.95 & 71.20 & 2.43 & -2.95 & 0.95 \\
\hline 113.75 & 0.95 & 58.30 & 1.65 & -2.94 & 0.94 \\
\hline 115.25 & 1.04 & 62.90 & 1.74 & -2.93 & 1.03 \\
\hline 118.25 & 0.95 & 58.90 & 1.68 & -2.91 & 0.94 \\
\hline 121.75 & 1.18 & 61.10 & 1.45 & -2.88 & 1.17 \\
\hline 123.25 & 1.16 & 56.10 & 1.25 & -2.87 & 1.15 \\
\hline 124.75 & 1.15 & 55.80 & 1.25 & -2.86 & 1.13 \\
\hline 127.75 & 1.15 & 56.50 & 1.36 & -2.84 & 1.07 \\
\hline 131.80 & 1.69 & 58.40 & 0.94 & -2.81 & 1.65 \\
\hline 151.80 & 1.04 & 66.10 & 1.94 & -2.68 & 1.03 \\
\hline 153.80 & 0.90 & 67.10 & 2.31 & -2.66 & 0.90 \\
\hline 156.80 & 1.13 & 61.00 & 1.53 & -2.64 & 1.12 \\
\hline 160.30 & 1.41 & 60.00 & 1.18 & -2.62 & 1.39 \\
\hline 163.70 & 1.39 & 57.80 & 1.12 & -2.59 & 1.37 \\
\hline 179.30 & 1.30 & 59.80 & 1.28 & -2.49 & 1.29 \\
\hline 182.30 & 1.06 & 57.00 & 1.43 & -2.47 & 1.05 \\
\hline 185.30 & 1.39 & 55.90 & 1.04 & -2.44 & 1.37 \\
\hline 188.85 & 1.59 & 55.90 & 0.92 & -2.42 & 1.57 \\
\hline 198.85 & 1.39 & 57.90 & 1.13 & -2.35 & 1.38 \\
\hline 201.85 & 1.50 & 59.20 & 1.10 & -2.33 & 1.48 \\
\hline 209.00 & 1.07 & 55.90 & 1.37 & -2.28 & 1.06 \\
\hline 210.20 & 1.06 & 61.30 & 1.67 & -2.27 & 1.05 \\
\hline 216.30 & 1.40 & 52.70 & 0.93 & -2.23 & 1.39 \\
\hline 217.60 & 1.61 & 50.00 & 0.73 & -2.22 & 1.59 \\
\hline 218.50 & 1.72 & 53.00 & 0.77 & -2.21 & 1.69 \\
\hline 226.60 & 1.65 & 54.70 & 0.86 & -2.16 & 1.63 \\
\hline 230.10 & 1.58 & 57.30 & 0.98 & -2.13 & 1.56 \\
\hline 232.50 & 1.63 & 53.20 & 0.82 & -2.12 & 1.61 \\
\hline 244.40 & 1.23 & 54.20 & 1.14 & -2.04 & 1.22 \\
\hline 245.80 & 1.33 & 54.30 & 1.05 & -2.03 & 1.32 \\
\hline 247.30 & 1.29 & 52.50 & 1.02 & -2.02 & 1.28 \\
\hline 255.30 & 1.45 & 52.60 & 0.91 & -1.96 & 1.43 \\
\hline 258.30 & 1.58 & 49.80 & 0.75 & -1.94 & 1.56 \\
\hline 266.30 & 1.44 & 49.30 & 0.81 & -1.88 & 1.43 \\
\hline 274.15 & 1.51 & 49.00 & 0.76 & -1.83 & 1.49 \\
\hline 277.30 & 1.62 & 52.70 & 0.82 & -1.81 & 1.61 \\
\hline 280.30 & 1.57 & 49.50 & 0.75 & -1.79 & 1.56 \\
\hline 293.30 & 1.39 & 55.20 & 1.05 & -1.70 & 1.38 \\
\hline 296.30 & 1.24 & 60.10 & 1.39 & -1.68 & 1.24 \\
\hline 299.30 & 1.50 & 50.20 & 0.81 & -1.66 & 1.49 \\
\hline
\end{tabular}

Appendix A (continued).

\begin{tabular}{|c|c|c|c|c|c|}
\hline \multirow[b]{2}{*}{$\begin{array}{l}\text { Depth } \\
\text { (mbsf) }\end{array}$} & \multirow[b]{2}{*}{$\begin{array}{c}K_{u} \\
\left(\mathrm{~W} / \mathrm{m} \cdot{ }^{\circ} \mathrm{C}\right)\end{array}$} & \multirow[b]{2}{*}{$\phi$} & \multicolumn{2}{|c|}{ Corrections } & \multirow[b]{2}{*}{$\underset{(\mathrm{W} / \mathrm{m}}{K_{c}} \cdot{ }^{\circ} \mathrm{C}$} \\
\hline & & & $\begin{array}{c}\text { pressure } \\
(\%)\end{array}$ & $\begin{array}{c}\text { temperature } \\
(\%)\end{array}$ & \\
\hline \multicolumn{6}{|l|}{ Hole $672 \mathrm{~A}$} \\
\hline 15.05 & 0.95 & 73.20 & 2.50 & -3.93 & 0.94 \\
\hline 18.05 & 0.88 & 78.10 & 3.07 & -3.91 & 0.87 \\
\hline 21.05 & 1.08 & 69.50 & 1.99 & -3.89 & 1.06 \\
\hline 24.55 & 1.11 & 79.10 & 2.50 & -3.86 & 1.09 \\
\hline 27.55 & 1.23 & 71.10 & 1.83 & -3.84 & 1.21 \\
\hline 30.55 & 1.40 & 67.20 & 1.44 & -3.82 & 1.37 \\
\hline 34.05 & 1.47 & 68.60 & 1.43 & -3.77 & 1.44 \\
\hline 37.05 & 1.37 & 74.00 & 1.78 & -3.72 & 1.34 \\
\hline 40.05 & 1,48 & 71.80 & 1.56 & -3.66 & 1.45 \\
\hline 43.55 & 1.12 & 67.80 & 1.84 & -3.58 & 1.10 \\
\hline 46.55 & 1.09 & 67.30 & 1.86 & -3.48 & 1.07 \\
\hline 49.55 & 1.14 & 70.10 & 1.93 & -3.39 & 1.12 \\
\hline 52.50 & 1.29 & 65.00 & 1.47 & -3.31 & 1.27 \\
\hline 55.40 & 1.34 & 63.70 & 1.36 & -3.27 & 1.31 \\
\hline 58.50 & 1.36 & 63.70 & 1.34 & -3.23 & 1.33 \\
\hline 62.30 & 1.25 & 67.10 & 1.62 & -3.18 & 1.23 \\
\hline 65.30 & 1.18 & 64.70 & 1.60 & -3.13 & 1.16 \\
\hline 68.30 & 1.21 & 66.10 & 1.63 & -3.09 & 1.19 \\
\hline 72.00 & 1.11 & 68.00 & 1.88 & -3.04 & 1.10 \\
\hline 75.00 & 1.16 & 63.70 & 1.58 & -3.00 & 1.14 \\
\hline 78.00 & 1.22 & 64.90 & 1.56 & -2.96 & 1.20 \\
\hline 81.50 & 1.25 & 69.20 & 1.73 & -2.91 & 1.24 \\
\hline 84.50 & 1.22 & 67.00 & 1.66 & -2.87 & 1.21 \\
\hline 87.50 & 1.32 & 62.00 & 1.32 & -2.83 & 1.30 \\
\hline 91.00 & 1.41 & 64.80 & 1.35 & -2.78 & 1.39 \\
\hline 94.00 & 1.24 & 68.30 & 1.70 & -2.73 & 1.23 \\
\hline 97.00 & 1.31 & 64.50 & 1.44 & -2.69 & 1.29 \\
\hline 100.55 & 1.17 & 67.30 & 1.76 & -2.64 & 1.16 \\
\hline 103.55 & 1.31 & 58.90 & 1.21 & -2.60 & 1.29 \\
\hline 106.55 & 1.30 & 60.10 & 1.27 & -2.56 & 1.28 \\
\hline 113.05 & 1.31 & 58.00 & 1.17 & -2.47 & 1.29 \\
\hline 144.55 & 1.17 & 69.60 & 1.89 & -2.03 & 1.17 \\
\hline 147.55 & 1.15 & 65.10 & 1.69 & -1.99 & 1.15 \\
\hline 163.80 & 1.15 & 74.20 & 2.17 & -1.76 & 1.16 \\
\hline 166.80 & 1.00 & 72.10 & 2.38 & -1.72 & 1.01 \\
\hline 192.10 & 1.01 & 74.10 & 2.50 & -1.37 & 1.02 \\
\hline 195.10 & 1.06 & 69.90 & 2.13 & -1.33 & 1.07 \\
\hline 197.60 & 1.19 & 65.80 & 1.68 & -1.29 & 1.19 \\
\hline \multicolumn{6}{|l|}{ Hole 673B } \\
\hline 2.25 & 1.05 & 74.80 & 2.25 & -4.17 & 1.03 \\
\hline 5.25 & 0.98 & 75.70 & 2.47 & -4.11 & 0.96 \\
\hline 18.71 & 1.19 & 66.40 & 1.58 & -3.87 & 1.16 \\
\hline 21.31 & 1.03 & 68.30 & 1.93 & -3.82 & 1.01 \\
\hline 23.68 & 1.10 & 70.00 & 1.90 & -3.77 & 1.08 \\
\hline 28.64 & 1.12 & 73.30 & 2.04 & -3.68 & 1.10 \\
\hline 30.14 & 1.19 & 72.20 & 1.87 & -3.65 & 1.17 \\
\hline 2.20 & 1.07 & 75.40 & 2.25 & -4.18 & 1.05 \\
\hline 9.80 & 1.10 & 73.40 & 2.08 & -4.07 & 1.08 \\
\hline 12.80 & 1.15 & 67.80 & 1.71 & -4.03 & 1.08 \\
\hline 15.80 & 1.19 & 70.40 & 1.79 & -3.99 & 1.16 \\
\hline 19.30 & 1.18 & 68.30 & 1.69 & -3.94 & 1.15 \\
\hline 22.30 & 1.10 & 69.50 & 1.87 & -3.89 & 1.08 \\
\hline 25.30 & 1.25 & 62.40 & 1.34 & -3.85 & 1.22 \\
\hline 28.80 & 1.25 & 66.80 & 1.53 & -3.80 & 1.23 \\
\hline 31.80 & 1.21 & 67.50 & 1.62 & -3.77 & 1.18 \\
\hline 34.80 & 1.32 & 60.00 & 1.17 & -3.73 & 1.29 \\
\hline 38.30 & 1.32 & 63.20 & 1.30 & -3.69 & 1.29 \\
\hline 41.30 & 1.17 & 66.90 & 1.65 & -3.65 & 1.14 \\
\hline 43.77 & 1.21 & 59.50 & 1.27 & -3.62 & 1.18 \\
\hline 47.85 & 1.22 & 64.50 & 1.48 & -3.57 & 1.19 \\
\hline 50.85 & 1.22 & 65.30 & 1.51 & -3.53 & 1.19 \\
\hline 53.85 & 1.19 & 66.80 & 1.62 & -3.49 & 1.17 \\
\hline 76.35 & 1.17 & 65.40 & 1.59 & -3.21 & 1.15 \\
\hline 79.35 & 1.11 & 62.50 & 1.53 & -3.18 & 1.09 \\
\hline 85.75 & 1.06 & 68.70 & 1.94 & -3.10 & 1.04 \\
\hline 95.46 & 1.22 & 68.60 & 1.68 & -2.98 & 1.20 \\
\hline \multicolumn{6}{|l|}{ Hole $674 \mathrm{~A}$} \\
\hline 5.25 & 1.22 & 62.80 & 1.35 & -4.07 & 1.19 \\
\hline 8.30 & 1.18 & 63.60 & 1.43 & -3.99 & 1.15 \\
\hline 10.20 & 1.33 & 57.70 & 1.05 & -3.94 & 1.29 \\
\hline 13.20 & 1.06 & 63.40 & 1.58 & -3.86 & 1.04 \\
\hline 17.85 & 1.18 & 68.00 & 1.62 & -3.74 & 1.16 \\
\hline
\end{tabular}


Appendix A (continued).

\begin{tabular}{|c|c|c|c|c|c|}
\hline \multirow[b]{2}{*}{$\begin{array}{l}\text { Depth } \\
\text { (mbsf) }\end{array}$} & \multirow[b]{2}{*}{$\begin{array}{c}K_{u} \\
\left(\mathrm{~W} / \mathrm{m}^{\circ} \cdot{ }^{\circ} \mathrm{C}\right)\end{array}$} & \multirow[b]{2}{*}{$\phi$} & \multicolumn{2}{|c|}{ Corrections } & \multirow[b]{2}{*}{$\frac{K_{c}}{\left(\mathrm{~W} / \mathrm{m} \cdot{ }^{\circ} \mathrm{C}\right)}$} \\
\hline & & & $\begin{array}{c}\text { pressure } \\
(\%)\end{array}$ & $\begin{array}{c}\text { temperature } \\
(\%)\end{array}$ & \\
\hline \multicolumn{6}{|c|}{ Hole 674A (Cont.) } \\
\hline 21.16 & 1.39 & 56.30 & 0.95 & -3.65 & 1.36 \\
\hline 27.35 & 1.13 & 63.70 & 1.50 & -3.52 & 1.11 \\
\hline 30.35 & 1.19 & 64.30 & 1.46 & -3.48 & 1.16 \\
\hline 73.10 & 1.22 & 64.20 & 1.42 & -2.90 & 1.20 \\
\hline 84.30 & 1.08 & 61.00 & 1.46 & -2.75 & 1.07 \\
\hline 87.30 & 1.27 & 71.40 & 1.69 & -2.71 & 1.26 \\
\hline 95.84 & 1.31 & 54.20 & 0.96 & -2.62 & 1.29 \\
\hline 106.35 & 1.38 & 53.60 & 0.89 & -2.57 & 1.35 \\
\hline 115.85 & 1.60 & 54.70 & 0.80 & -2.52 & 1.57 \\
\hline 150.70 & 1.30 & 59.50 & 1.17 & -2.35 & 1.28 \\
\hline 166.30 & 1.19 & 59.60 & 1.29 & -2.27 & 1.18 \\
\hline 199.80 & 1.39 & 54.60 & 0.94 & -2.03 & 1.37 \\
\hline 201.30 & 1.46 & 58.00 & 1.00 & -2.02 & 1.45 \\
\hline 220.40 & 1.21 & 55.00 & 1.10 & -1.92 & 1.20 \\
\hline 223.34 & 1.15 & 54.70 & 1.14 & -1.91 & 1.14 \\
\hline 239.30 & 1.24 & 60.10 & 1.28 & -1.84 & 1.23 \\
\hline 253.67 & 1.51 & 48.70 & 0.70 & -1.75 & 1.40 \\
\hline 274.50 & 1.30 & 43.90 & 0.66 & -1.62 & 1.29 \\
\hline 375.75 & 1.32 & 54.20 & 1.01 & -1.12 & 1.32 \\
\hline 378.70 & 1.35 & 44.10 & 0.66 & -1.11 & 1.34 \\
\hline 388.30 & 1.22 & 53.00 & 1.05 & -1.05 & 1.22 \\
\hline 409.90 & 1.19 & 57.10 & 1.24 & -0.92 & 1.20 \\
\hline 429.70 & 1.30 & 55.60 & 1.09 & -0.80 & 1.30 \\
\hline 432.70 & 1.29 & 60.10 & 1.28 & -0.78 & 1.30 \\
\hline 435.85 & 1.46 & 52.80 & 0.88 & -0.76 & 1.46 \\
\hline 440.35 & 1.62 & 46.30 & 0.61 & -0.73 & 1.62 \\
\hline 443.78 & 1.33 & 47.30 & 0.78 & -0.71 & 1.33 \\
\hline 451.16 & 1.74 & 47.90 & 0.61 & -0.67 & 1.74 \\
\hline \multicolumn{6}{|l|}{ Hole $676 \mathrm{~A}$} \\
\hline 2.25 & 1.03 & 77.50 & 2.64 & -4.14 & 1.01 \\
\hline 5.25 & 1.01 & 77.30 & 2.68 & -4.03 & 1.00 \\
\hline 11.45 & 1.04 & 72.90 & 2.32 & -3.82 & 1.02 \\
\hline 20.95 & 1.22 & 65.80 & 1.62 & -3.48 & 1.20 \\
\hline 30.45 & 1.23 & 64.20 & 1.54 & -3.26 & 1.21 \\
\hline 36.95 & 1.11 & 73.90 & 2.25 & -3.18 & 1.10 \\
\hline 46.45 & 1.12 & 63.30 & 1.65 & -3.09 & 1.10 \\
\hline 55.90 & 1.13 & 70.30 & 2.01 & -3.11 & 1.12 \\
\hline 65.40 & 1.23 & 64.80 & 1.58 & -3.08 & 1.21 \\
\hline 74.95 & 1.15 & 66.20 & 1.76 & -2.86 & 1.14 \\
\hline 80.90 & 1.38 & 57.10 & 1.10 & -2.76 & 1.36 \\
\hline 83.70 & 1.38 & 61.40 & 1.27 & -2.71 & 1.36 \\
\hline 86.70 & 1.37 & 56.10 & 1.07 & -2.66 & 1.35 \\
\hline 93.90 & 1.32 & 59.10 & 1.23 & -2.54 & 1.30 \\
\hline 96.90 & 1.38 & 57.50 & 1.12 & -2.49 & 1.36 \\
\hline 103.20 & 1.34 & 60.10 & 1.26 & -2.40 & 1.32 \\
\hline 106.20 & 1.38 & 58.30 & 1.15 & -2.37 & 1.36 \\
\hline 112.95 & 1.29 & 62.60 & 1.42 & -2.30 & 1.28 \\
\hline 115.95 & 1.41 & 59.10 & 1.16 & -2.27 & 1.39 \\
\hline 131.78 & 1.31 & 63.40 & 1.44 & -2.11 & 1.30 \\
\hline 144.45 & 1.32 & 54.70 & 1.07 & -1.99 & 1.31 \\
\hline 151.00 & 1.25 & 62.90 & 1.49 & -1.92 & 1.24 \\
\hline 154.00 & 1.21 & 64.40 & 1.61 & -1.88 & 1.21 \\
\hline 160.40 & 1.16 & 64.80 & 1.70 & -1.80 & 1.16 \\
\hline 163.50 & 1.29 & 62.40 & 1.42 & -1.76 & 1.29 \\
\hline 170.00 & 1.20 & 71.80 & 2.02 & -1.68 & 1.20 \\
\hline 173.00 & 1.18 & 67.00 & 1.79 & -1.64 & 1.18 \\
\hline 179.40 & 1.14 & 70.00 & 2.02 & -1.56 & 1.15 \\
\hline 182.50 & 1.24 & 65.10 & 1.62 & -1.52 & 1.24 \\
\hline 188.88 & 1.19 & 66.10 & 1.73 & -1.44 & 1.20 \\
\hline 191.48 & 1.21 & 65.50 & 1.68 & -1.41 & 1.21 \\
\hline 198.47 & 1.11 & 65.60 & 1.84 & -1.32 & 1.12 \\
\hline 201.47 & 1.13 & 67.00 & 1.88 & -1.28 & 1.14 \\
\hline 207.95 & 1.18 & 71.50 & 2.05 & -1.21 & 1.19 \\
\hline 210.95 & 1.27 & 70.60 & 1.86 & -1.17 & 1.28 \\
\hline 217.45 & 1.26 & 59.10 & 1.32 & -1.09 & 1.26 \\
\hline 236.03 & 1.11 & 67.40 & 1.95 & -0.87 & 1.12 \\
\hline 236.40 & 1.11 & 67.20 & 1.94 & -0.86 & 1.12 \\
\hline 245.80 & 1.19 & 65.10 & 1.70 & -0.75 & 1.20 \\
\hline 248.76 & 1.12 & 70.20 & 2.09 & -0.72 & 1.14 \\
\hline
\end{tabular}


APPENDIX B

Summary of temperature and heat-flow data from each hole on ODP Leg 110. Here, $z$ is the depth interval between successive measurements, $R(z)$ is the thermal resistance over that depth interval, and $\Sigma R(z)$ is the cumulative thermal resistance. Thermal graidents, $d T / d z$, and heat flow, $Q$, are listed for each depth interval and for intervals of interest including more than two temperatures. The thermal conductivity of the surface sediments was assumed to be $0.85 \mathrm{~W} / \mathrm{m} \cdot{ }^{\circ} \mathrm{C}$.

$\left.\begin{array}{rrrccccc}\hline \text { Hole } & \begin{array}{c}\text { Depth } \\ (\mathrm{mbs})\end{array} & \begin{array}{c}z \\ (\mathrm{~m})\end{array} & \begin{array}{c}\Sigma R(z) \\ \left({ }^{\circ} \mathrm{C} \cdot \mathrm{m}^{2} / \mathrm{W}\right)\end{array} & \begin{array}{c}R(z) \\ \left({ }^{\circ} \mathrm{C} \cdot \mathrm{m}^{2} / \mathrm{W}\right)\end{array} & \begin{array}{c}T \\ \left({ }^{\circ} \mathrm{C}\right)\end{array} & \begin{array}{c}d T / d z \\ \left({ }^{\circ} \mathrm{C} / \mathrm{km}\right)\end{array} & \begin{array}{c}Q \\ \left(\mathrm{~mW} / \mathrm{m}^{2}\right)\end{array} \\ \hline 671 \mathrm{~B} & & & & & & & \\ & 0.0 & 17.4 & 0.0 & 16.92 & 2.26 & 114^{1} \\ & 17.4 & 19.0 & 16.92 & 16.91 & 4.25 & 92 \\ & 36.4 & 131.2 & 33.83 & 112.71 & 6.00 & 36\end{array}\right\} 105^{1} \begin{gathered}118 \\ 167.6\end{gathered}$

$672 \mathrm{~A}$

$\left.\begin{array}{rrrrrr}0.0 & & 0.0 & 14.91 & 2.14 & 108^{\prime} \\ 13.3 & 13.3 & 14.91 & 17.88 & 3.57 & 38 \\ 32.3 & 19.0 & 32.79 & 4.30 & & 95 \\ 42.3 & 10.0 & 40.37 & 5.25 & 167 \\ 51.3 & 9.0 & 48.15 & 7.99 & 6.75 & 72\end{array}\right\} \begin{gathered}96 \\ 41 \\ 133.8\end{gathered}$

$673 \mathrm{~A}$

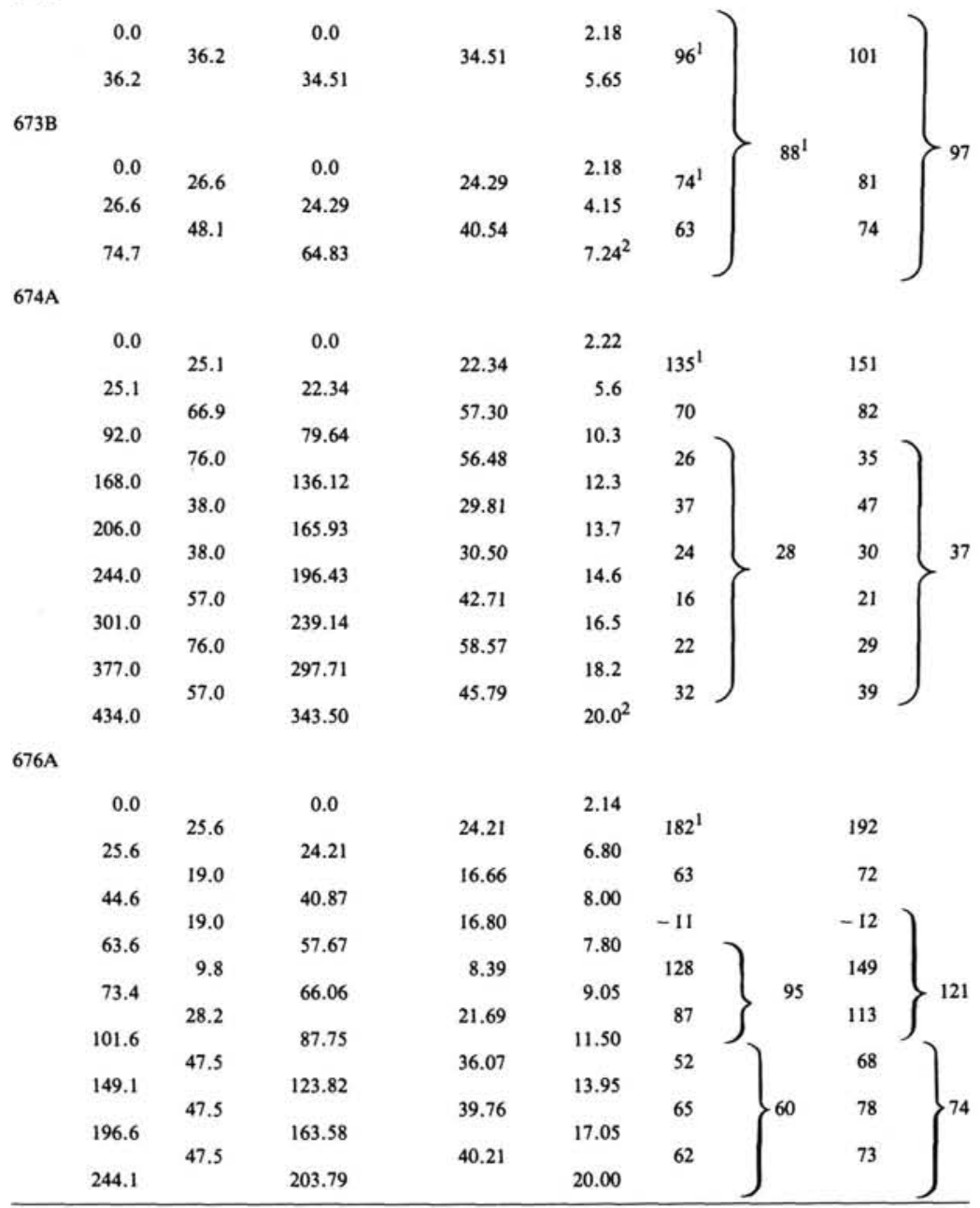

${ }^{1}$ Gradient forced through bottom-water temperature at $z=0$.

2 Temperature is a lower bound. 